\title{
A relationship between deep-sea benthic oxygen demand and oceanic primary productivity
}

\author{
John P. CHRISTENSEN * \\ Bigelow Laboratory for Ocean Sciences, 180 McKown Point, West Boothbay Harbor, Maine 04575, USA
}

Received 10 November 1998; revised 16 June 1999; accepted 15 September 1999

\begin{abstract}
A diagenetic model of porewater $\mathrm{O}_{2}$ was used to examine the relationship between organic carbon flux to the sediments and benthic oxygen demand (BOD). The model predicted that the organic carbon influx to sediments balances BOD as long as sediments are oxygenated. The critical rate occurs when $\mathrm{O}_{2}$ at infinite depth disappears. With influxes exceeding the critical rate, the $\mathrm{O}_{2}$ flux into the sediments via molecular diffusion can not consume all incoming organic matter, and anaerobic conditions result in BOD underestimating the carbon influx. Given that low rates of deep-sea BOD approximate the carbon influx below $9 \mathrm{~g} \cdot \mathrm{C} \cdot \mathrm{m}^{-2} \cdot \mathrm{y}^{-1}$, a significant multilinear regression was found between published $\mathrm{BOD}$, primary productivity $\left(\mathrm{P}_{\mathrm{p}}\right.$, both in $\left.\mathrm{g} \cdot \mathrm{C} \cdot \mathrm{m}^{-2} \cdot \mathrm{y}^{-1}\right)$, and water depth $(\mathrm{X}, \mathrm{m}), \mathrm{BOD}=19.6537 * \mathrm{X}^{-0.936411 *} \mathrm{P}_{\mathrm{p}}^{1.139487}$. Using this, BOD and the carbon flux to $1000 \mathrm{~m}$ were mapped worldwide. Global organic carbon fluxes to $1000 \mathrm{~m}$ totaled $2328 \mathrm{MT} \cdot \mathrm{C} \cdot \mathrm{y}^{-1}(1$ MT $\left.\mathrm{C}=10^{12} \mathrm{~g}\right), 6 \%$ of the overlying primary productivity. The global BOD was $739 \mathrm{MT} \cdot \mathrm{C} \cdot \mathrm{y}^{-1}, 32 \%$ of the $1000 \mathrm{~m}$ flux. For southern and northern hemispheres, the $1000 \mathrm{~m}$ carbon flux was similar $(1178$ and 1149 MT $\cdot C \cdot y^{-1}$ ), while BOD differed (356 and $383 \mathrm{MT} \cdot \mathrm{C} \cdot \mathrm{y}^{-1}$ ). Polar regions did not differ in their relationship of vertical carbon export to productivity. (C) 2000 Ifremer/CNRS/IRD/Éditions scientifiques et médicales Elsevier SAS
\end{abstract}

deep-sea / oxygen / primary productivity / respiration / sediments

Résumé - Relation entre la demande en oxygène benthique et la production primaire. La relation entre la production primaire et la demande en oxygène benthique des fonds marins (BOD) a été examinée de deux manières différentes: a) en utilisant un modèle diagénétique de concentrations en oxygène d'eau de porosité pour examiner la relation entre le flux de carbone organique vers les sédiments et la BOD, et b) en se basant sur une analyse statistique de la relation entre la production primaire et le flux de carbone vers les sédiments. Le modèle diagénétique prédit que, lorsque l'enfouissement de carbone organique est insignifiant, l'afflux de carbone organique vers les sédiments est en équilibre avec la BOD aussi longtemps que de l'oxygène est présent dans toute la colonne de sédiment. Le taux critique est atteint lorsque l'oxygène devient zéro à une profondeur infinie et les équations de définition sont présentées. Avec des afflux de carbone organique supérieurs à ce taux critique, le flux d'oxygène entrant dans les sédiments par diffusion moléculaire est insuffisant pour métaboliser toute la matière organique d'arrivée. Des conditions anaérobies en résultent et la BOD sédimentaire peut sous-estimer l'afflux du carbone. Le taux critique dépend directement du coefficient de dégradation exponentiel de la matière organique de sorte que, lorsque ce coefficient est plus grand, davantage de matière organique métabolisable est reminéralisée plus près de la surface sédimentaire et le taux critique est plus grand. Étant donné que des taux bas de BOD doivent être voisins de l'afflux de carbone, les taux de BOD dans les sédiments de fonds marins publiés ont été examinés en fonction de leur relation avec la productivité primaire en zone

\footnotetext{
*Correspondence and reprints: jchristensen@bigelow.org
} 
euphotique $\left(\mathrm{P}_{\mathrm{p}}\right)$. On a constaté une régression multilinéaire significative, $\mathrm{BOD}=19.6537 * \mathrm{X}^{-0,936411 *} \mathrm{P}_{\mathrm{p}}^{-1,139487}$, où $\mathrm{BOD}$ et $\mathrm{P}_{\mathrm{p}}$ sont exprimés en $\mathrm{g} \mathrm{C} \cdot \mathrm{m}^{-2} \cdot \mathrm{y}^{-1}$ et la profondeur de l'eau $(\mathrm{X})$ en $\mathrm{m}$. À partir des données de BOD, le taux critique empirique était environ de $9 \mathrm{~g} \cdot \mathrm{C} \mathrm{m}^{-2} \cdot \mathrm{y}^{-1}$. La BOD prédite par la régression a une incertitude d'un facteur ou deux environ dans la plupart des régions de fonds marins. En se basant sur des cartes globales de productivité et de profondeur d'eau, la régression a été utilisée pour répertorier la distribution de BOD dans le monde entier en utilisant un quadrillage de latitude et longitude de 5 minutes. Les océans Pacifique, Atlantique, Indien, Antarctique et Arctique ont une BOD sédimentaire cumulative de 310, 204, 175, 19, 31 $\mathrm{MT} \cdot \mathrm{C} \cdot \mathrm{y}^{-1}$ pour un total global de $739 \mathrm{MT} \cdot \mathrm{C} \cdot \mathrm{y}^{-1}\left(1 \mathrm{MT} \mathrm{C}=10^{12} \mathrm{~g}\right)$. De nombreuses zones de hautes latitudes étaient dépourvues d'estimation de productivité, c'est pourquoi ces totaux sont bas. Les flux de carbone à une profondeur de $1000 \mathrm{~m}$ étaient de $1043,632,531,61,61 \mathrm{MT} \cdot \mathrm{C} \cdot \mathrm{y}^{-1}$, respectivement pour un total global de 2328 $\mathrm{MT} \cdot \mathrm{C} \cdot \mathrm{y}^{-1}$. En moyenne, le flux de carbone organique à $1000 \mathrm{~m}$ comprenait $6 \%$ de la productivité primaire de recouvrement, tandis que les sédiments ont consommé $32 \%$ du flux à $1000 \mathrm{~m}$. Relativement à l'hémisphère nord, l'hémisphère sud a une surface océanique de plus de $45 \%$ mais la productivité par $\mathrm{m}^{2}$ n'est que de $75 \%$. Il en résulte que le flux de carbone à $1000 \mathrm{~m}$ est environ le même pour les deux hémisphères (1 178 par rapport à $1149 \mathrm{MT} \cdot \mathrm{C} \cdot \mathrm{y}^{-1}$, sud et nord), tandis que la BOD sédimentaire est moindre dans le sud $\left(356 \mathrm{MT} \cdot \mathrm{C} \cdot \mathrm{y}^{-1}\right)$ que dans le nord (383 $\left.\mathrm{MT} \cdot \mathrm{C} \cdot \mathrm{y}^{-1}\right)$. Sur la base de productivités mesurées directement, la BOD sédimentaire dans les régions polaires recouvertes de glace suit de près la relation prédite, laissant à penser que ces régions ne diffèrent pas dans leur relation de transport de carbone vertical avec la productivité. C 2000 Ifremer/CNRS/IRD/Éditions scientifiques et médicales Elsevier SAS

\section{fonds marins / oxygène / production primaire / respiration / sédiments}

\section{INTRODUCTION}

Metabolism in deep-sea sediments is fueled by the input of usable organic matter to the sea bed [17, 40]. The majority of this incoming organic matter is thought to be supplied by the sinking rain of material from productivity in the overlying euphotic zone [7, $50,53]$, with minor amounts being due to the influx of sediments and entrained organic matter in turbidity flows from shallower depths or from lateral organic matter transport at mid-depths [49, 52]. Rates of primary productivity have been correlated with fluxes of sinking organic carbon into the deep-sea as measured in sediment traps $[4,6,34,35,38,41,56]$. If overlying productivity is responsible for the organic matter supply to deep-sea sediments, then there should be a relationship between productivity and deep-sea sediment metabolism similar to the ones found for sediment traps. Here, the relationships between benthic oxygen demand (BOD), organic matter influx to the sediments, and overlying primary productivity were examined using diagenetic models of oxygen utilization in sediments, a global map of primary productivity, and data from well oxygenated deep-sea sediments.

\section{METHODS AND RESULTS}

\subsection{Diagenetic pore water oxygen model}

Organic carbon inflow to the sediments drives both the metabolism and the long-term burial of carbon. In most sediments, burial represents a small fraction of the total so that to reasonable approximation, the carbon influx balances respiration [17]. When carbon influx is low, as in most deep-sea sediments, oxygenbased metabolism predominates, and oxygen concentrations remain high throughout the near-surface sediments. Here, measured oxygen fluxes would be expected to reflect the total sediment metabolism [45]. On the other hand, if the carbon influx is large, oxygen becomes depleted within a short distance of the sediment-water interface. In this condition, suboxic and anaerobic metabolisms would utilize some of the carbon influx, and oxygen respiration would underestimate the true carbon oxidation [44]. Thus, in the simplest sense, direct measurements of the benthic oxygen demand would be expected to approximate that of the carbon influx when influxes are low and would underestimate carbon influxes when these influxes are high. In order to better appreciate 
the non-linear effects of oxygen demand on carbon influxes, a simple pore water oxygen diagenetic model was constructed.

The model considered long-term steady state conditions where carbon oxidation within the sediments balanced diffusion of oxygen and sedimentation [5].

$\phi \mathrm{D} \frac{\partial^{2} \mathrm{C}}{\partial \mathrm{z}^{2}}-\phi \mathrm{w} \frac{\partial \mathrm{C}}{\partial \mathrm{z}}-\phi \mathrm{R}_{\mathrm{z}}=0$

Porosity ( $\phi, \mathrm{mL}$ of seawater $\mathrm{cm}^{-3}$ of total sediments) was considered constant with depth. The diffusivity $\left(\mathrm{D}, \mathrm{cm}^{2} \cdot \mathrm{s}^{-1}\right)$ was molecular. Depth $(\mathrm{z}, \mathrm{cm})$ was positive downwards. Oxygen concentrations (C) were in nmol $\mathrm{O}_{2} \cdot \mathrm{mL}^{-1}$. Sedimentation $\left(\mathrm{w}, \mathrm{cm} \cdot \mathrm{s}^{-1}\right)$ was assumed constant at $1 \mathrm{~cm} / 1000 \mathrm{y}$. The rate of oxygen consumption at any depth was $\mathrm{R}_{\mathrm{z}}\left(\mathrm{nmol} \mathrm{O}_{2}\right.$ $\mathrm{mL}^{-1} \cdot \mathrm{s}^{-1}$ ). I considered two vertical zones within this model.

One zone was a diffusive boundary layer of seawater adjacent to the sediment surface. No sediments or oxygen consumption rate existed within this boundary layer. The depth of this zone $\left(Z_{z 1}, \mathrm{~cm}\right)$ was assumed to have fixed values of $0,0.020$ and $0.10 \mathrm{~cm}$. Given the boundary conditions,

$0 \leq \mathrm{Z}_{\mathrm{i}} \leq \mathrm{Z}_{\mathrm{z} 1}$,

$\mathrm{C}_{\mathrm{i}}=\mathrm{C}_{\mathrm{o}}$ at $\mathrm{Z}_{\mathrm{i}}=0$

$\mathrm{C}_{\mathrm{i}}=\mathrm{C}_{\mathrm{z} 1}$ at $\mathrm{Z}_{\mathrm{i}}=\mathrm{Z}_{\mathrm{z} 1}$,

the solution of the oxygen profile was,

$$
\begin{gathered}
\mathrm{C}_{\mathrm{i}}=\mathrm{C}_{\mathrm{o}}-\left(\mathrm{C}_{\mathrm{o}}-\mathrm{C}_{\mathrm{z} 1}\right)^{*}\left[1-\exp \left(\mathrm{wZ}_{\mathrm{i}} / \mathrm{D}_{1}\right)\right] \\
/\left[1-\exp \left(\mathrm{wZ} Z_{\mathrm{z} 1} / \mathrm{D}_{1}\right)\right],
\end{gathered}
$$

where $\mathrm{C}_{\mathrm{o}}$ was the oxygen concentration in the bottom water, $\mathrm{C}_{\mathrm{z} 1}$ was the oxygen concentration at the bottom of the boundary layer. The diffusivity in this first layer $\left(\mathrm{D}_{1}\right)$ was the molecular coefficient $\left(1.23 \times 10^{-5}\right.$ $\left.\mathrm{cm}^{2} \cdot \mathrm{s}^{-1}\right)$ in seawater at $3{ }^{\circ} \mathrm{C}$.

The second zone, denoted by a subscript of 2 , was the sediment layer starting at a depth of $Z_{z 1}$. Here, molecular diffusivity was corrected for tortuosity and porosity [57].

$\mathrm{D}_{2}=\mathrm{D}^{*} \phi^{2}$

Porosity was fixed at $0.8 \mathrm{~mL}$ of porewater $/ \mathrm{cm}^{3}$ of whole sediment. The oxygen utilization rate, $R_{z}$, was assumed to decrease exponentially with depth away from the sediment surface, $Z_{z 1}$.
$\mathrm{R}_{\mathrm{z}}=\mathrm{R}_{\mathrm{z} 1} \exp \left(-\mathrm{b}\left(\mathrm{Z}_{\mathrm{i}}-\mathrm{Z}_{\mathrm{z} 1}\right)\right)$

The rate at the sediment surface was $R_{z 1}$ $\left(\mathrm{nmol} \cdot \mathrm{mL}^{-1} \cdot \mathrm{s}^{-1}\right)$, and $\mathrm{b}$ was the exponential decay coefficient $\left(\mathrm{cm}^{-1}\right)$ of the rate with depth. The total oxygen utilization over the entire sediment column, $\mathrm{R}_{\text {total }}$ in $\mathrm{nmol} \mathrm{cm}(\mathrm{mL} \cdot \mathrm{s})^{-1}$, was,

$\mathrm{R}_{\text {total }}=\mathrm{R}_{\mathrm{z1}} / \mathrm{b}$,

as found by integrating equation 4 between the depths of $Z_{z 1}$ and infinity. The total respiration rate in the sediment column $\left(\mathrm{R}_{\text {total }}\right)$ was related to the organic carbon influx $\left(F_{c}, g \cdot C \cdot m^{-2} \cdot y^{-1}\right)$ by,

$\mathrm{F}_{\mathrm{c}}=\mathrm{R}_{\text {total }} \phi_{2}(106 / 138) / \mathrm{f}_{1}$,

which was based on molar Redfield stoichiometry of carbon to oxygen, and where $f_{1}$ converted units of carbon influx to units of $\mathrm{nmol} \mathrm{O}_{2} \mathrm{~cm}(\mathrm{~mL} \cdot \mathrm{s})^{-1}$. The concentration profile of oxygen was analytically calculable as long as the concentration at all depths were greater than zero. Given the boundary conditions,

$\mathrm{Z}_{\mathrm{z} 1}<\mathrm{Z}_{\mathrm{i}}<\infty$,

$\mathrm{C}_{\mathrm{z} 1}=\mathrm{C}_{\mathrm{i}}$ at $\mathrm{Z}_{\mathrm{i}}=\mathrm{Z}_{\mathrm{z} 1}$,

$\mathrm{C}_{\infty}=\mathrm{C}_{\mathrm{i}}$ at $\mathrm{Z}_{\mathrm{i}}=\infty$,

the solution for the oxygen profile was,

$\mathrm{C}_{\mathrm{i}}=\mathrm{C}_{\mathrm{z} 1}-\left[\mathrm{A}^{*}\left(1-\exp \left(-\mathrm{b}\left(\mathrm{Z}_{\mathrm{i}}-\mathrm{Z}_{\mathrm{z} 1}\right)\right)\right]\right.$,

where $A=R_{z 1} /\left[b\left(D_{2} b+w\right)\right]$. The concentration at the boundary of the two zones $\left(\mathrm{C}_{\mathrm{z} 1}\right)$ was found by balancing at $Z_{z 1}$ both the concentration predicted by each zonal equation and the flux calculated from each concentration profile. From this, the concentration at the interface between the two zones was,

$$
\begin{aligned}
\mathrm{C}_{\mathrm{z} 1}= & {\left[\phi_{1} \mathrm{C}_{\mathrm{o}}-\phi_{2}^{*}\left(\mathrm{D}_{2} / \mathrm{w}\right)^{*}\left(\mathrm{R}_{\mathrm{z1}} /\left(\mathrm{D}_{2} \mathrm{~b}+\mathrm{w}\right)\right)^{*}(1-\mathrm{M})\right] } \\
& /\left(\mathrm{N}+\phi_{2}\right),
\end{aligned}
$$

where,

$\mathrm{N}=\left(\phi_{1}-\phi_{2}\right) * \mathrm{M}$,

$\mathrm{M}=\exp \left(-\mathrm{w} Z_{\mathrm{z} 1} / \mathrm{D}_{1}\right)$.

Subscripts 1 and 2 referred to parameters for zone 1 and zone 2, respectively. As no sediments exist in zone $1, \phi_{1}=1$. The concentration at infinite depth was calculated,

$$
\begin{gathered}
\mathrm{C}_{\infty}=\left[\phi_{1}^{*} \mathrm{C}_{\mathrm{o}} /\left(\mathrm{N}+\phi_{2}\right)\right]-\left\{\left[\mathrm{R}_{\mathrm{z1}} /\left(\mathrm{wb}\left(\mathrm{D}_{2} \mathrm{~b}+\mathrm{w}\right)\right]\right.\right. \\
\left.*\left[\left(\phi_{2}(1-\mathrm{M}) \mathrm{D}_{2} \mathrm{~b} /\left(\mathrm{N}+\phi_{2}\right)\right)+\mathrm{w}\right]\right\} .
\end{gathered}
$$


Equations 7-9 described the situation where the carbon influx was less than or equal to the maximum diffusive influx of oxygen needed to maintain a permanently oxygenated sediment column. If the carbon influx were to exceed this critical level, oxygen would be depleted from the sediment column. By setting $\mathrm{C}_{\infty}$ of equation 9 to zero, the critical carbon flux was

$$
\mathrm{R}_{\text {critical }}=\mathrm{C}_{\mathrm{o}} /\left[\left(\phi_{2}(1-\mathrm{M}) / \phi_{1} \mathrm{w}\right)+\left(\mathrm{M} /\left(\phi_{1}\left(\mathrm{D}_{2} \mathrm{~b}+\mathrm{w}\right)\right)\right] .\right.
$$

If the carbon influx (expressed as $\mathrm{R}_{\text {total }}$ in equations 5 and 6) was less than or equaled this critical level $\left(\mathrm{R}_{\text {critical }}\right)$, then oxygen concentrations would remain at or above zero at all depths in the sediments. If on the other hand, the carbon influx exceeded this critical quantity, the carbon flux would exceed the ability of oxygen to be supplied to the sediments, oxygen would be depleted at some finite depth and anaerobic metabolism at depth would occur. From equation 10, the critical flux was directly dependent on b (figure 1). Since $b$ defined the exponential decrease in the decay rate of organic matter, a greater than $b$ would yield a greater fraction of the metabolism at a shallower depth in the sediments, as might be envisioned if a more easily metabolizable organic matter were

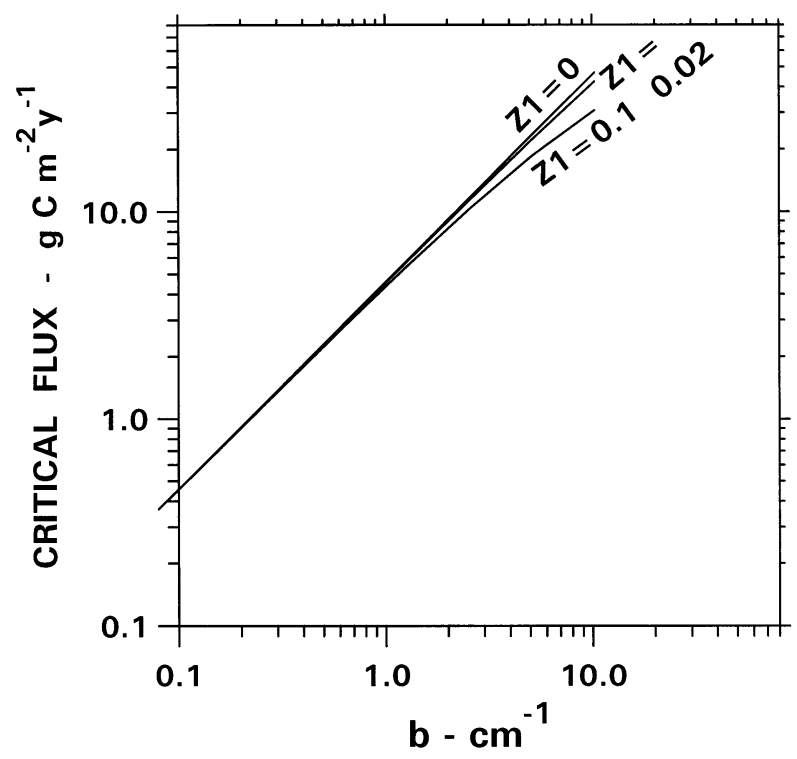

Figure 1. Relationship between the critical flux and the exponential decay coefficient (b) for sedimentary oxygen consumption. For increasing thicknesses of the diffusive boundary layer ( $\mathrm{Z} 1$ in $\mathrm{cm})$, the critical flux was reduced relative to the condition with no boundary layer $(\mathrm{Z} 1=0)$. supplied. A lesser value of $\mathrm{b}$ would increase the proportion of the material which is degraded at depth, suggesting a composition which is less easily metabolized. The relationship between the critical rate and $\mathrm{b}$ can be envisioned in that with a larger $\mathrm{b}$, material was decomposed more quickly and nearer the sediment-water interface. Since more of the rate occurred nearer the bottom water source of oxygen, a greater amount of material could thus be decomposed aerobically. Also, model results showed that a thicker diffusive boundary layer acted to impede the diffusion of oxygen into the sediments. At larger values of the coefficient, $b$, the thickest diffusive boundary thickness, $Z_{z 1}$, reduced the BOD by as much as $35 \%$ from the conditions with no boundary layer (figure 1).

If the carbon influx should exceed this critical level, then the oxygen supply would be insufficient to oxidize all the organic matter, and this limitation would set the conditions allowing for anaerobic metabolism. To model this situation, the boundary conditions for the sediment zone were,

$\mathrm{Z}_{\mathrm{z} 1} \leq \mathrm{Z}_{\mathrm{i}} \leq \mathrm{Z}_{\mathrm{b}}<\infty$,

Flux $_{\mathrm{i}}=\phi_{2} \mathrm{D}_{2}\left(\partial \mathrm{C}_{\mathrm{i}} / \partial \mathrm{z}\right)-\phi_{2} \mathrm{wC}_{\mathrm{i}}$,

$\mathrm{C}_{\mathrm{b}}=0$ at $\mathrm{Z}_{\mathrm{i}}=\mathrm{Z}_{\mathrm{b}}$ and,

Flux $_{\mathrm{b}}=0$ at $\mathrm{Z}_{\mathrm{i}}=\mathrm{Z}_{\mathrm{b}}$.

Here, zone 1 was identical to the above low flux model, and zone 2 was similar. In particular, the rate of organic matter decay was exponentially decreasing as defined in equation 4 , but at the point where oxygen reached zero, this rate stopped being an oxygen utilization rate and switched to an unspecified anaerobic metabolic pathway. Because an analytical solution was not found, a numerical finite centereddifference solution was used to calculate the results over the aerobic portion of the sediments. The numerical sediment solution was coupled to the analytical diffusive boundary model, so that the oxygen concentration at the top of the sediments was $\mathrm{C}_{\mathrm{z} 1}$.

The profile of oxygen over this zone was determined by dividing the zone into at least 400 depth increments, determining the tridiagonal matrix for the centered-difference equations and solving the tridiagonal matrix using the Gauss-Jordan iteration [29]. After this solution, the profile did not necessarily meet all the required conditions, because two vari- 


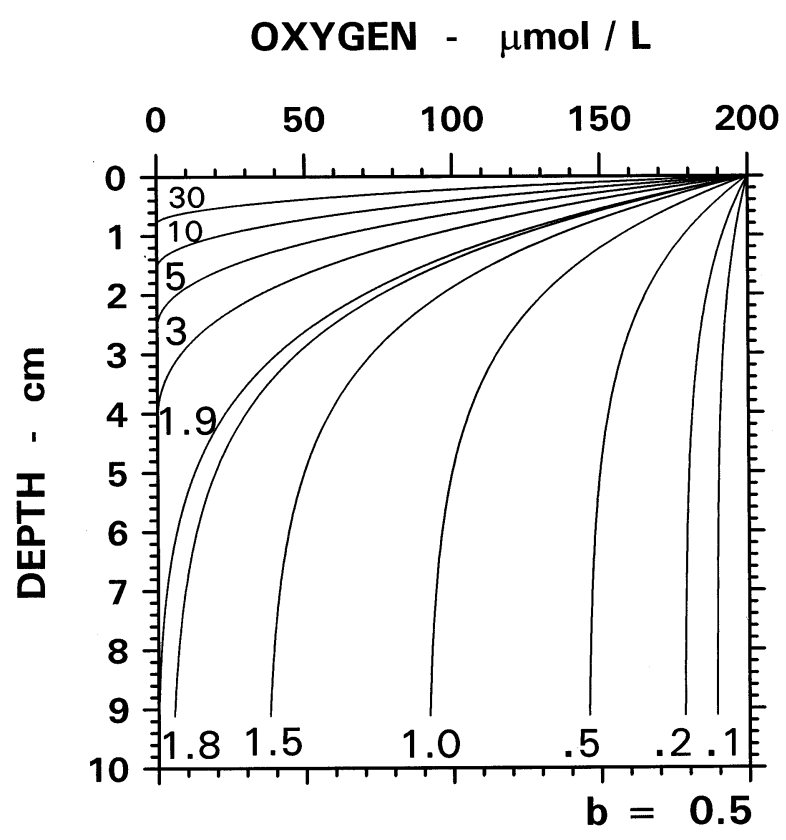

Figure 2. Oxygen concentration profiles in sediments for different inputs of organic carbon. The organic carbon input $\left(\mathrm{g} \cdot \mathrm{C} \cdot \mathrm{m}^{-2} \cdot \mathrm{y}^{-1}\right)$ was listed near each profile. This series of profiles was calculated analytically for fully aerobic sediments and numerically for partially anaerobic sediments. The critical flux was about $1.83 \mathrm{~g} \cdot \mathrm{C} \cdot \mathrm{m}^{-2} \cdot \mathrm{y}^{-1}$. No diffusive boundary layer was included, and the exponential decay coefficient was $0.5 \mathrm{~cm}^{-1}$.

ables needed to be determined uniquely. First, the depth at which oxygen goes to zero had to be specified. This depth was initially guessed as some small depth. The procedure then calculated an estimate of the true oxygen profile, and the fluxes at the top and bottom of zone 2 were determined from this estimated profile. The profile was accepted as final if the flux at the bottom of zone 2 was less than $0.1 \%$ of the top flux. If not, the depth was increased by adding additional depth increments to the previous depth, and then the profile and fluxes reevaluated. The second parameter to be evaluated was the concentration at the boundary between the two zones. This concentration was initially set at bottom water oxygen content. After successful solution of the bottom depth, the flux at the top of the sediment zone was compared with the bottom flux within the diffusive boundary zone. If the two did not match, the estimated concentration at the boundary was lessened, and then the process iterated (the bottom zone oxygen profile was determined, then the flux at the top of the sediments calculated and compared with the bottom flux for the boundary zone). The solution was accepted when the two fluxes at the boundary agreed within $0.01 \%$ of each other. At carbon influxes very close to the critical flux, the solution from the numerical scheme equaled the results from the analytical solution.

Using solutions for both fully and partially aerobic sediments, this solution scheme was used to calculate oxygen profiles based on different levels of the carbon influx and on different values of the exponential decay coefficient (figure 2). One outcome was that relatively small changes in the carbon influx had dramatic changes on the oxygen profiles. Based on the coefficient $\mathrm{b}$ being 0.5 , oxygen concentrations at infinite depth decreased from about $100 \mu \mathrm{mol} / \mathrm{L}$ with a flux of $0.9 \mathrm{~g} \cdot \mathrm{C} \cdot \mathrm{m}^{-2} \cdot \mathrm{y}^{-1}$ to zero $\mu \mathrm{mol} / \mathrm{L}$ with a flux of $1.9 \mathrm{~g} \cdot \mathrm{C} \cdot \mathrm{m}^{-2} \cdot \mathrm{y}^{-1}$. Continued increase in the flux by a factor of 2 yielded an oxygen penetration of only about $4 \mathrm{~cm}$. This suggests that a 4 -fold change in the carbon inputs can shift the sediments from highly aerobic to observably anaerobic, a result previously noted by Rabouille and Gaillard [45, 46]. By summing the aerobic respiration rate over the aerobic zone and comparing it with the carbon input, the percentage of organic matter which was oxidized aerobically was evaluated. The importance of aerobic respiration decreased from $100 \%$ to $80 \%$ by an increase of 2-3-fold in the carbon influx $(b=0.5$, figure $3 a$ ). The presence of a thick diffusive boundary layer noticeably decreased the percent aerobic respiration (figure $3 a$ ).

The relationship between the carbon influx and benthic oxygen demand was also examined (figure $3 b$ ). Given low fluxes of carbon into the sediments, both the carbon influx and the benthic oxygen demand were equal since all organic matter was oxidized by oxygen. But at fluxes above the critical level, the benthic oxygen demand calculated by the model drops from the 1:1 relationship with carbon influx (figure $3 b$ ). For the three curves representing the selected $b$ values, the non-linear portions all followed similar curvature although the critical rate separating linear from non-linear regions occurred at successively greater carbon influxes for increasing values of $\mathrm{b}$ (figures $3 b, 1$ ). These results showed that any relationship of oxygen flux to carbon influx will likely be linear at low fluxes and may become non-linear at higher fluxes. In the following section, the goal was to 

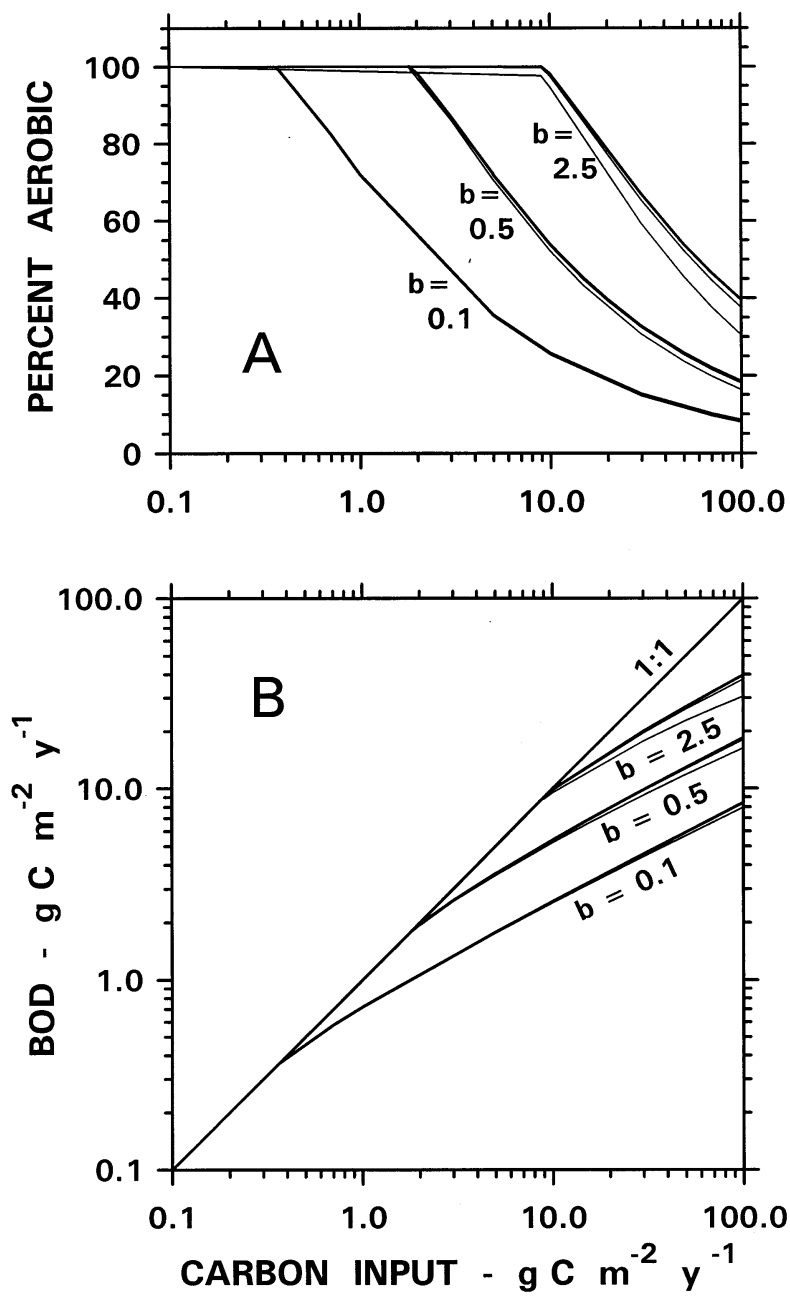

Figure 3. (A) Model relationship between percent aerobic consumption of organic matter within the sediments and organic carbon input. At carbon inputs less than the critical flux, all organic matter consumption was aerobic. At higher fluxes, the proportion of aerobic respiration decreased dramatically. The critical flux was greater for larger values of the exponential decay coefficient $\left(\mathrm{b}\right.$ in $\left.\mathrm{cm}^{-1}\right)$. Each set of curves represented the results for one value of $b$ (listed next to the curves) and for three different thicknesses of the diffusive boundary layer $(0,0.02$, and $0.1 \mathrm{~cm})$, with the greatest aerobic respiration being supported with the thinnest boundary layer.

(B) The modeled relationship of benthic oxygen demand relative to organic carbon input. A linear relationship (line marked 1:1) existed when carbon inputs were less than the critical level, while greater inputs supported an increased proportion of anaerobic metabolism. Each family of curves represented the results for the listed value of $b$ and for three different diffusive boundary layer thicknesses $(0,0.02$, and $0.1 \mathrm{~cm})$. The upper line of each family of curves represented the thinnest boundary layer. examine deep-sea data in order to evaluate an average critical level differentiating a linear region from a non-linear region for the deep-sea.

\subsection{Deep-sea BOD data}

A large number of studies have measured the benthic oxygen demand in the deep-sea [10, 31, 47]. These data were initially screened so that BOD rates were less than $50 \mathrm{~g} \cdot \mathrm{C} \cdot \mathrm{m}^{-2} \cdot \mathrm{y}^{-1}$ and were from sites with well oxygenated bottom waters (bottom water oxygen concentrations greater than $100 \mu \mathrm{mol} \cdot \mathrm{kg}^{-1}$, table $I$, figure 4). BOD has been measured in a variety of ways, but I included only data measured by the three most common methods, oxygen microelectrodes used either in situ or on shipboard, and in situ chamber incubations. Water column depth and station locations were taken from the original reference. From these station locations, primary productivities were selected based on the global map of primary productivity of Longhurst et al. [37]. That map was oriented on squares of one degree latitude and longitude. When the benthic stations were located within 0.1 degree of a productivity grid boundary (an integer latitude or longitude), the selected productivity was the average of productivities of the adjacent grid squares.

Using this data, a multilinear regression was performed based on the equation:

$\mathrm{BOD}=\mathrm{B} 0 * \mathrm{X}^{\mathrm{B} 1} * \mathrm{P}_{\mathrm{p}}^{\mathrm{B} 2}$

where BOD was the benthic oxygen demand $(\mathrm{g} \cdot \mathrm{C}$ $\left.\mathrm{m}^{-2} \cdot \mathrm{y}^{-1}\right), \mathrm{X}$ was the water depth in meters, $P_{\mathrm{p}}$ was the primary productivity $\left(\mathrm{g} \cdot \mathrm{C} \cdot \mathrm{m}^{-2} \cdot \mathrm{y}^{-1}\right)$, and the coefficients, B0, B1, and B2 were determined by regression. The resulting regression was significant (table $I I)$, and the coefficients and their standard errors were,

$\ln (\mathrm{B} 0)=2.978264 \pm 2.033391$

B0 $=19.653659$,

$\mathrm{B} 1=-0.9364112 \pm 0.2070542$

$\mathrm{B} 2=1.1394872 \pm 0.1176099$.

Graphs of the estimated BOD at fixed water depths versus increasing values of primary productivity were presented along with actual sediment data from sites 
Table I. Benthic oxygen demand (BOD), water depth, primary productivity $\left(\mathrm{P}_{\mathrm{p}}\right.$, [37]), and BOD methods which were used in multilinear regression. Methods were in situ microelectrode (im), shipboard microelectrode (sm), and in situ benthic chamber (ic). References (Ref.) are from the literature list.

\begin{tabular}{|c|c|c|c|}
\hline $\begin{array}{l}\text { BOD } \\
\mathrm{gC} / \mathrm{m}^{2} \mathrm{y}\end{array}$ & $\begin{array}{l}\text { Depth } \\
\mathrm{m}\end{array}$ & $\begin{array}{l}\mathrm{P}_{\mathrm{p}} \\
\mathrm{gC} / \mathrm{m}^{2} \mathrm{y}\end{array}$ & Method \& Ref. \\
\hline 1.144 & 4910 & 82 & ic [3] \\
\hline 0.841 & 4910 & 82 & $\operatorname{sm}[3]$ \\
\hline 1.312 & 4440 & 120 & ic [3] \\
\hline 2.792 & 4440 & 120 & ic [3] \\
\hline 1.211 & 4660 & 100 & ic [3] \\
\hline 2.166 & 3856 & 146 & $\mathrm{sm}[13]$ \\
\hline 2.893 & 4710 & 103 & $\operatorname{sm}[16]$ \\
\hline 1.312 & 4600 & 92 & $\operatorname{sm}[16]$ \\
\hline 2.12 & 4395 & 96 & $\operatorname{sm}[16]$ \\
\hline 2.961 & 4240 & 112 & $\operatorname{sm}[16]$ \\
\hline 1.447 & 4540 & 125 & $\operatorname{sm}[16]$ \\
\hline 2.187 & 4200 & 161 & sm [16] \\
\hline 1.749 & 4550 & 128 & $\operatorname{sm}[16]$ \\
\hline 1.918 & 4460 & 133 & $\operatorname{sm}[16]$ \\
\hline 1.918 & 4730 & 127 & sm [16] \\
\hline 12.448 & 2321 & 283 & sm [20] \\
\hline 13.794 & 2005 & 232 & sm [20] \\
\hline 14.13 & 3095 & 206 & ic [20] \\
\hline 6.392 & 2321 & 283 & im [20] \\
\hline 7.065 & 3095 & 206 & im [20] \\
\hline 1.682 & 4986 & 90 & im [20] \\
\hline 0.889 & 2322 & 72 & $\operatorname{im}[23]$ \\
\hline 1.636 & 2335 & 72 & im [23] \\
\hline 1.618 & 2966 & 73 & im [23] \\
\hline 2.489 & 4236 & 143 & sm [24] \\
\hline 1.936 & 4501 & 113 & sm [24] \\
\hline 1.106 & 5210 & 110 & sm [24] \\
\hline 1.198 & 5380 & 102 & sm [24] \\
\hline 2.765 & 4526 & 172 & im [33] \\
\hline 2.765 & 4600 & 146 & sm [33] \\
\hline 3.687 & 2760 & 137 & $\operatorname{sm}[33]$ \\
\hline 2.765 & 5036 & 142 & sm [33] \\
\hline 3.042 & 3858 & 158 & sm [33] \\
\hline 1.843 & 4950 & 145 & sm [33] \\
\hline 1.659 & 5102 & 107 & sm [33] \\
\hline 1.659 & 5358 & 62 & sm [33] \\
\hline 8.849 & 3110 & 367 & ic [32] \\
\hline 1.659 & 2972 & 82 & ic [32] \\
\hline 0.802 & 4439 & 73 & ic [32] \\
\hline 7.031 & 2000 & 243 & ic [36] \\
\hline 6.022 & 2000 & 243 & ic [36] \\
\hline 10.093 & 2000 & 243 & ic [36] \\
\hline 2.402 & 4800 & 157 & ic [36] \\
\hline 5.45 & 4980 & 157 & ic [42] \\
\hline 12.007 & 2880 & 342 & ic [42] \\
\hline 5.623 & 3706 & 420 & $\operatorname{im}[48]$ \\
\hline 4.056 & 4074 & 299 & im [48] \\
\hline 2.857 & 4078 & 299 & ic [48] \\
\hline 3.41 & 4078 & 299 & ic [48] \\
\hline
\end{tabular}

Table I. (Continued)

\begin{tabular}{llll}
\hline $\begin{array}{l}\text { BOD } \\
\mathrm{gC} / \mathrm{m}^{2} \mathrm{y}\end{array}$ & $\begin{array}{l}\text { Depth } \\
\mathrm{m}\end{array}$ & $\begin{array}{l}\mathrm{P}_{\mathrm{p}} \\
\mathrm{gC} / \mathrm{m}^{2} \mathrm{y}\end{array}$ & Method \& Ref. \\
\hline 1.009 & 4300 & 96 & ic [50] \\
1.178 & 4300 & 96 & ic [50] \\
1.043 & 4300 & 96 & ic [50] \\
1.144 & 4300 & 96 & ic [50] \\
1.077 & 4300 & 96 & ic [50] \\
1.043 & 4300 & 96 & ic [50] \\
0.774 & 4300 & 96 & ic [50] \\
0.942 & 4300 & 96 & ic [50] \\
1.043 & 4300 & 96 & ic [50] \\
8.593 & 3815 & 389 & ic [51] \\
3.503 & 4400 & 115 & ic [51] \\
0.676 & 4900 & 85 & ic [51] \\
0.544 & 5900 & 97 & ic [51] \\
3.253 & 3600 & 299 & ic [53] \\
\hline
\end{tabular}

within $500 \mathrm{~m}$ of the fixed depth (figure 5). The relationship between carbon inputs (the regression estimated BOD) and measured BOD in figures 6 and 7 was comparable to the earlier theoretical plot (figure 3b).

As the regression was evaluated as the natural log of equation 12a, the confidence limit (CL) for any regression estimated BOD was,

$\mathrm{CL}=\exp \left[\ln \left(\mathrm{BOD}_{\mathrm{est}}\right)+/-\mathrm{f}_{\mathrm{p}}^{*} \mathrm{SE}_{\text {est }}\right]$

where $f_{p}$ was the factor converting the standard error to overall confidence limit at desired probability level, and $\mathrm{SE}_{\text {est }}$ was the standard error of the estimated BOD. Because the quantity on the right in equation 16 can be separated into $\mathrm{BOD}_{\text {est }}^{*} \exp \left(\mathrm{f}_{\mathrm{p}}^{*} \mathrm{SE}_{\mathrm{est}}\right)$ or $\mathrm{BOD}_{\text {est }} / \exp \left(\mathrm{f}_{\mathrm{p}}^{*} \mathrm{SE}_{\mathrm{est}}\right)$, the error of the estimates was presented as the error factor, $\exp \left(\mathrm{SE}_{\text {est }}\right)$, a multiple or divisor of the estimated BOD (figure 8). The error factor was relatively constant at $1.5-1.91$ for productivities ranging from 10 to $1000 \mathrm{~g} \cdot \mathrm{C} \cdot \mathrm{m}^{-2} \cdot \mathrm{y}^{-1}$ and for all depths below $1000 \mathrm{~m}$. Thus, the regression predicted an estimated BOD with an uncertainty of $0.52-1.91$ times the estimated BOD (using $\mathrm{f}_{\mathrm{p}}=1$ ). Above $1000 \mathrm{~m}$, the error factors increased to 2.0 2.46 at $200 \mathrm{~m}$ (figure 8).

The variability of the three different methods of measuring BOD (microelectrodes versus chambers) were compared based on the absolute value of the deviation of individual data from the regression (irrespective of whether the deviation is positive or nega- 
tive relative to the regression's estimate), where deviations were expressed as percent of each data's estimated BOD. Here, the average of these was interpreted as a measure of the method's variability with respect to correlation with productivity and depth. For in situ microelectrodes, these deviations averaged $29 \%$ of the data's BOD $(n=9)$, while for shipboard microelectrodes, these deviations averaged $33 \%(\mathrm{n}=25)$. For in situ chambers, they averaged $39 \%(\mathrm{n}=29)$. Thus, because in situ microelectrodes had the lowest average, this method appears to be slightly better correlated with overlying productivity and depth than does either shipboard microelectrodes or in situ chambers. In order to compare the overall sampling bias for each method, I used another statistic, the average deviation around the regression. This average deviation includes the sign of the deviation and should equal zero for perfect correlation. These were found to be low for each of the methods. For in situ microelectrodes, the deviations averaged -0.50 $\mathrm{g} \cdot \mathrm{C} \cdot \mathrm{m}^{-2} \cdot \mathrm{y}^{-1}$, or an average of $-3.2 \%$ of each estimated BOD. For shipboard microelectrodes, the deviations averaged $+0.66 \mathrm{~g} \cdot \mathrm{C} \cdot \mathrm{m}^{-2} \cdot \mathrm{y}^{-1}(+24.1 \%$ of the estimated BODs). For in situ chambers, they averaged $-0.16 \mathrm{~g} \cdot \mathrm{C} \cdot \mathrm{m}^{-2} \cdot \mathrm{y}^{-1}(-0.3 \%$ of the estimated BODs). Because each method's average estimate of bias was less than each method's variability given above, the results of the regression showed no evidence for large bias by any of the three methods.

\subsection{Global distributions}

Given this statistically-significant regression between primary productivity, water depth, and benthic oxygen demand, global maps of primary productivity and topography were used to map the distribution of estimated BOD and the estimated carbon flux at a fixed depth of $1000 \mathrm{~m}$. Topography was based on the ETOPO5 global topography distributed by U.S. National Oceanic and Atmospheric Administration, which gives average depth or elevation centered at five minute latitude and longitude spacing. The productivity map of Longhurst et al. [37], being on a one degree latitude and longitude grid with the named location as the upper right corner of the square, was transposed onto the grid of ETOPO5, with one alteration. The integer latitude and longitude points on ETOPO5 fit equally well under either two productiv- ity grid squares (for the edges of adjacent $1^{\circ} \times 1^{\circ}$ squares) or four productivity grid squares (at the corners of the one degree squares). At these positions, the productivities on the integer degree grid lines in the new five minute grid were the respective averages. From this compilation, sediment BOD, standard error of the estimate, and estimated carbon flux at $1000 \mathrm{~m}$ water depth were calculated for all ocean areas with depths equal to or exceeding $200 \mathrm{~m}$ (about $7 \times 10^{6}$ grid points over all oceans), although grid points with water depths less than $1000 \mathrm{~m}$ depth were not used in any of the subsequent calculations. Distributions of the BOD and $1000 \mathrm{~m}$ flux, averaged areally onto one degree squares, were presented in figures 9,10. The global distribution data, either for the five minute grid (230 megabytes) or for the one degree grid (2.6 megabytes), are available upon request.

The results were cumulated over ten degree latitudinal bands for each of the major ocean basins, the Atlantic, Pacific, Indian, Antarctic and Arctic Oceans (figure 4, table III). Each grid point was adjusted for area based on its position in a spherical planet of radius $6371.22 \mathrm{~km}$. Not all of the topographic grid points have corresponding productivities, so the proportion of the ocean area within each latitudinal band which lacked productivity data was calculated (table III). Generally this uncertainty was less than $2 \%$ within the latitudinal band and was attributed to the inability of the coarse grid spacing (productivity data) from following coastlines as well as the fine grid spacing (topography data). At higher latitudes, ice cover and cloudiness caused a significant proportion (as much as $100 \%$ ) of the selected region from being analyzed. Nevertheless, given the data as it is, the total BOD for the Atlantic was $204 \mathrm{MT}-\mathrm{C} \cdot \mathrm{y}^{-1}$ $\left(\mathrm{MT}=10^{12} \mathrm{~g} \cdot \mathrm{C}\right)$, the Pacific was $310 \mathrm{MT}-\mathrm{C} \cdot \mathrm{y}^{-1}$ and the Indian was $175 \mathrm{MT}-\mathrm{C} \cdot \mathrm{y}^{-1}$ (table IV). The Atlantic had higher per meter productivity (136 $\left.\mathrm{g} \cdot \mathrm{C} \cdot \mathrm{m}^{-2} \cdot \mathrm{y}^{-1}\right)$ than did the other two oceans (111 and $113 \mathrm{~g} \cdot \mathrm{C} \cdot \mathrm{m}^{-2} \cdot \mathrm{y}^{-1}$ for the Pacific and Indian Oceans, respectively). Also, sediments in the Atlantic and Indian Oceans were somewhat shallower than those in the Pacific. Both factors would allow more carbon to reach the sediments. BOD as percentage of overlying productivity averaged $2.02 \%$ in the Atlantic, $1.79 \%$ in the Pacific, and $2.00 \%$ in the Indian. When the organic carbon flux at a constant depth $(1000 \mathrm{~m})$ was considered, the deep Atlantic received 


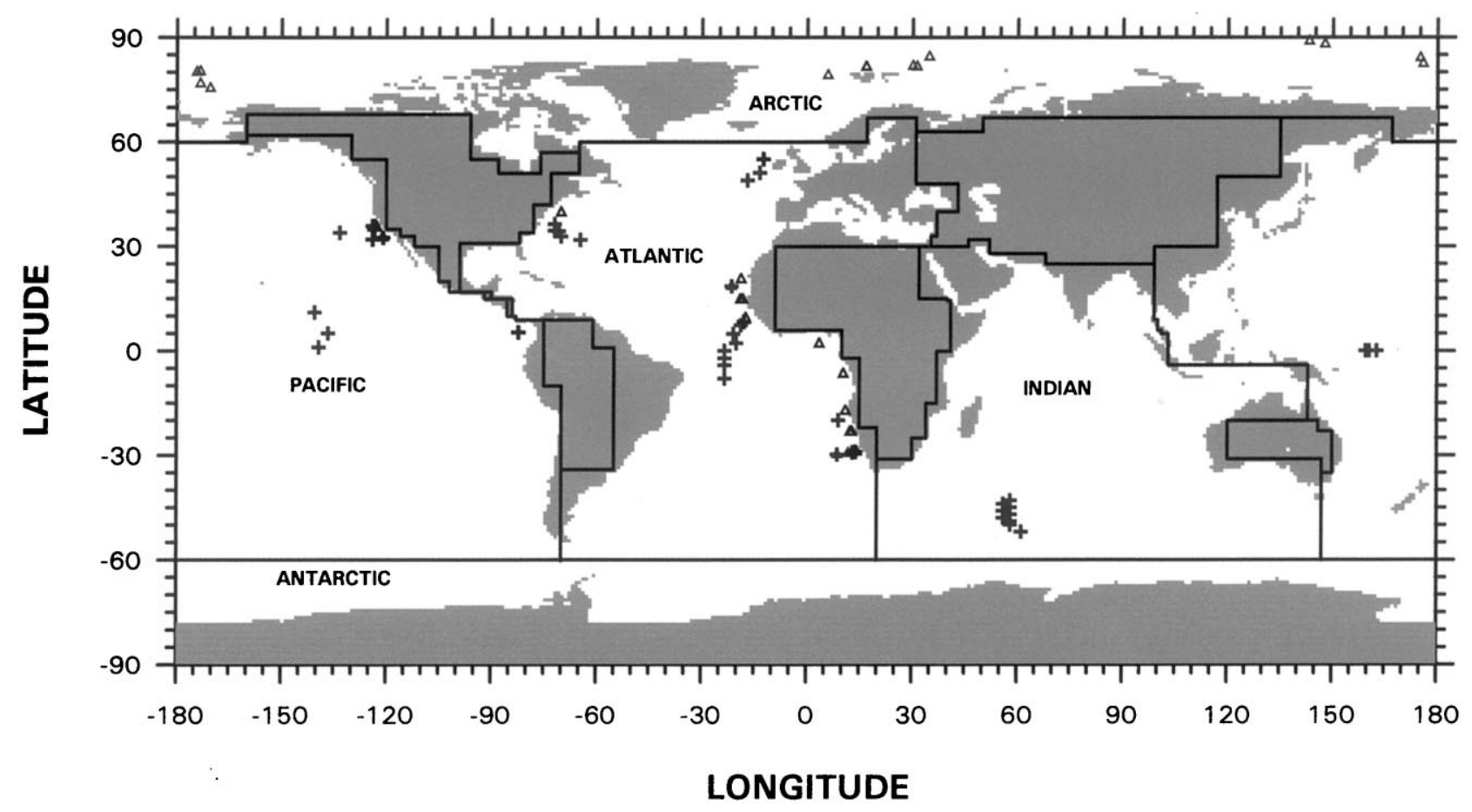

Figure 4. Locations of deep-sea sediment stations used in the regression of BOD and primary productivity (crosses) or used for reference (triangles). Dark lines denote the ocean regions used in calculating areal sums.

Table II. Analysis of variance table for multilinear regression.

\begin{tabular}{lccc}
\hline Source of variation & Degrees of freedom & Sum of squares & Mean square \\
\hline Regression & 2 & 31.4467 & 15.7233 \\
Deviations & 60 & 10.0314 & 0.1672 \\
Total & 62 & 41.4781 & 0.6690 \\
\hline
\end{tabular}

$632 \mathrm{MT} \cdot \mathrm{C} \cdot \mathrm{y}^{-1}$, the deep Pacific collected 1043 $\mathrm{MT} \cdot \mathrm{C} \cdot \mathrm{y}^{-1}$, and $531 \mathrm{MT} \cdot \mathrm{C} \cdot \mathrm{y}^{-1}$ settled into the deep Indian Ocean. The influxes represented $6.25 \%$ of the primary productivity in the Atlantic, $6.02 \%$ in the Pacific, and $6.07 \%$ in the Indian Ocean (table IV). The Arctic and Antarctic Oceans contributed little to the global total ( $<4 \%$ each), but much of the area in each region was not included because of the lack of satellite pigment data.

By summing over all oceans, a latitudinal description of the fluxes can be made (figure 11). Per ten degree latitudinal band, areally summed primary productivity (MT-C $\cdot \mathrm{y}^{-1}$ ) showed two peaks of high rates, at $40-50^{\circ} \mathrm{S}$ and around the equator, while a third peak of lesser magnitude occurred at $40-50^{\circ} \mathrm{N}$. The area of deep ocean (greater than $1000 \mathrm{~m}$ ) was greatest between $20^{\circ} \mathrm{N}$ and $40^{\circ} \mathrm{S}$, and co-occurred with the highest productivity peaks. A significant reduction in the area of the ocean north of $20^{\circ} \mathrm{N}$ contributes to the lower areally summed productivity peak at $40-$ $50^{\circ} \mathrm{N}$. The carbon flux at $1000 \mathrm{~m}$ mirrors the pattern in productivity, but at about $6 \%$ of its magnitude. The deep sea BOD also approximates this pattern except that the much shallower water depths found above $50^{\circ} \mathrm{N}$ affect the BOD relative to the carbon flux at $1000 \mathrm{~m}$. The northern and southern hemispheres were also compared. The southern hemisphere had about $10 \%$ greater total productivity $\left(19842 \mathrm{MT} \cdot \mathrm{y}^{-1}\right)$ than did the northern hemisphere $\left(18298 \mathrm{MT} \cdot \mathrm{y}^{-1}\right)$, but this was solely due to the $45 \%$ greater area of ocean in the southern hemisphere. Average productivity per square meter was less in the south $\left(103 \mathrm{~g} \cdot \mathrm{C} \cdot \mathrm{m}^{-2} \cdot \mathrm{y}^{-1}\right)$ than in the north $(138$ 
$\left.\mathrm{g} \cdot \mathrm{C} \cdot \mathrm{m}^{-2} \cdot \mathrm{y}^{-1}\right)$. Combined with the lower productivity per square meter in the southern hemisphere, the organic carbon flux to $1000 \mathrm{~m}$ was about the same magnitude in both hemispheres (1 178 and 1149 MT$\mathrm{C} \cdot \mathrm{y}^{-1}$ in the south versus the north). However, since the southern ocean was deeper on average than oceans in the northern hemisphere, the sediment consumption was less in the southern hemisphere than in the northern one (356 and $383 \mathrm{MT} \cdot \mathrm{C} \cdot \mathrm{y}^{-1}$ respectively).

\section{DISCUSSION}

In this report, the link between primary productivity in the overlying ocean and deep-sea benthic

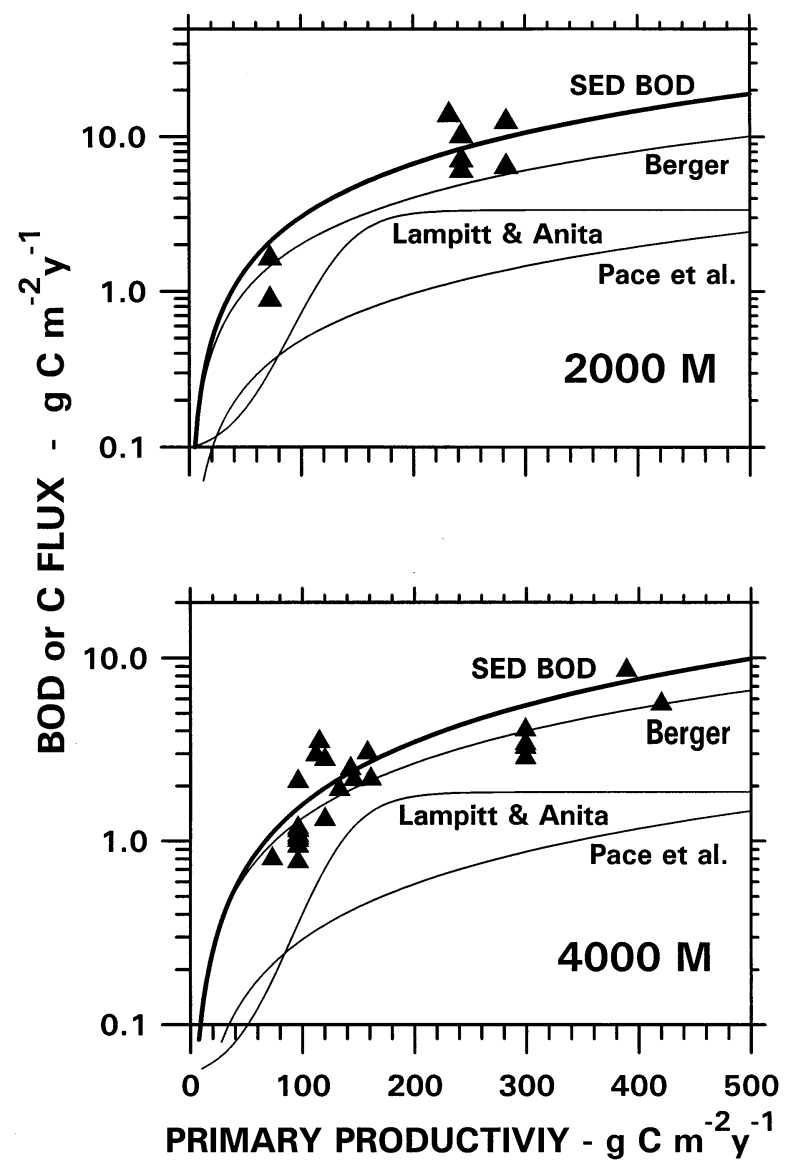

Figure 5. Relationship of regression-predicted carbon fluxes or measured BOD to primary productivity at 2000 and $4000 \mathrm{~m}$ depth. Regressions from this report (SED BOD), and from [41] listed as Pace et al. [4] listed as Berger as utilized in Jahnke [31], and from Lampitt and Anita [35]. Measured sediment BOD were plotted when the actual sampling site was within $500 \mathrm{~m}$ of the depth used in the regression.

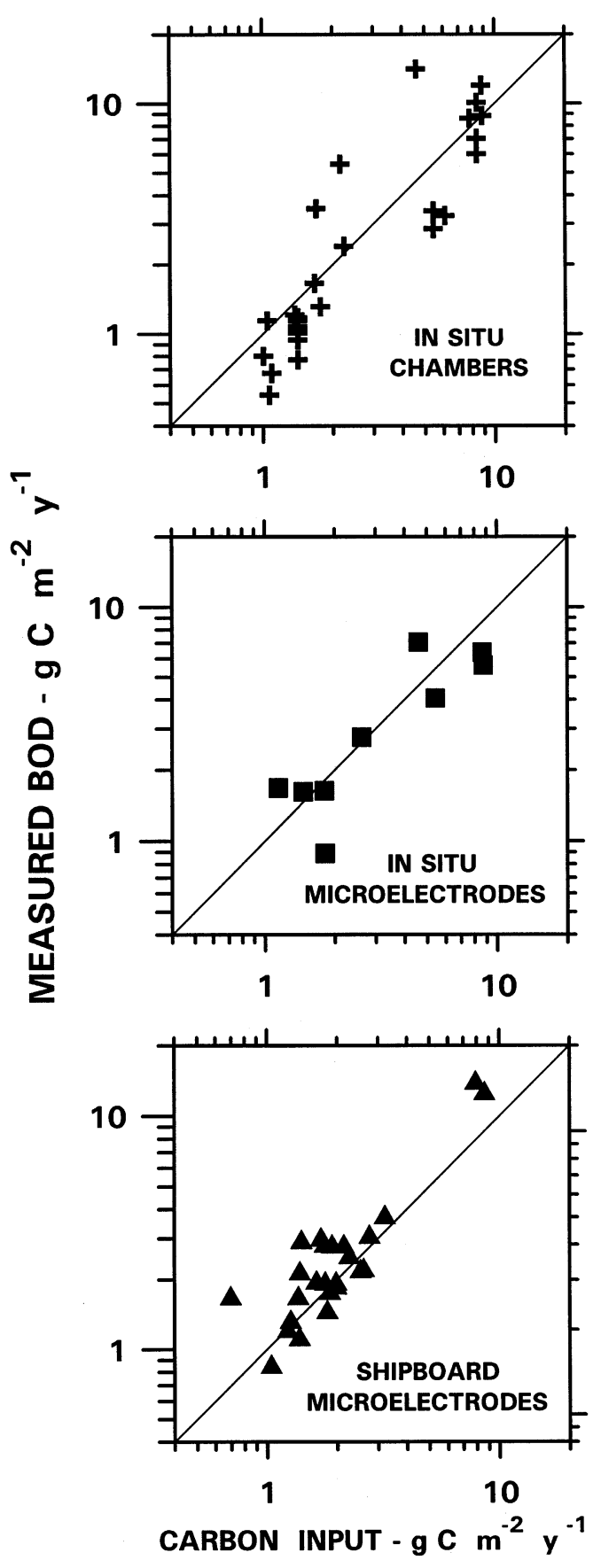

Figure 6. Relationships of measured BOD to the carbon inputs calculated from regression. Results of the three sampling methods (in situ chambers, in situ microelectrodes, and shipboard microelectrodes) were presented separately.

metabolism was examined. A simple diagenetic model of oxygen in sediments was constructed based on a 
single type of reacting organic matter with an exponentially decreasing reaction rate, no diffusion and reoxidation of reduced compounds moving up from depth, molecular diffusion of oxygen, and the occurrence of a diffusive boundary layer above the sediments. The oxygen model indicated that a linear relationship would exist between the organic carbon input to the sediments and the oxygen respiration up to a critical value of the carbon input. Above this critical value, oxygen could not enter the sediments by molecular diffusion quickly enough to maintain a fully aerobic sediment column. The model suggested that linearity could be approximated within $20 \%$ when the carbon influx was a factor of 2-3 above this critical flux, but more dramatic increases in the flux of incoming organic matter would cause significant deviations from the 1:1 relationship. In addition, this critical flux was directly dependent on the reac-

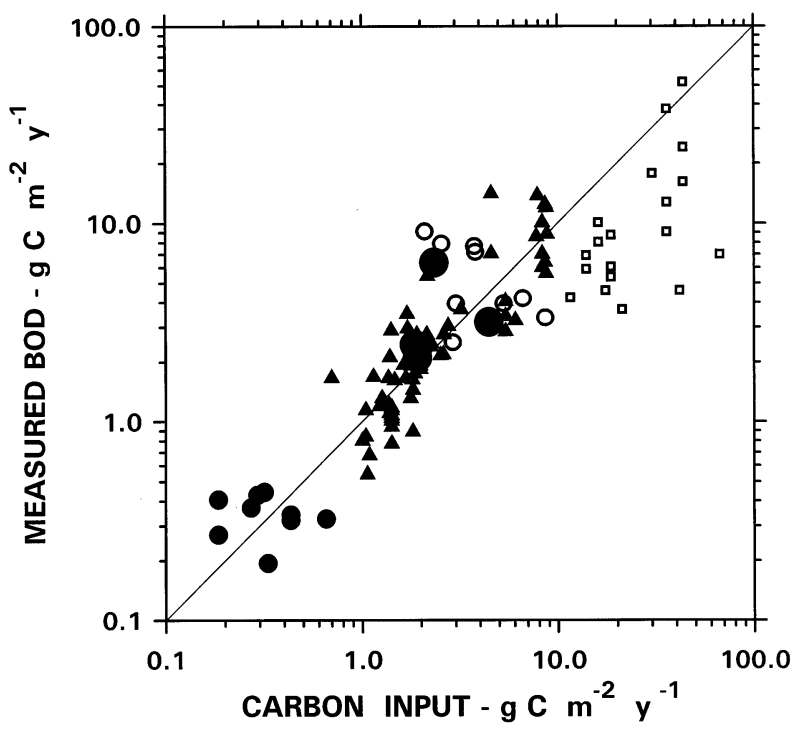

Figure 7. Relationship of measured BOD to organic carbon inputs calculated by regression. The gray triangles were all data used in the regression. The open squares represented data for higher flux sites which were excluded from the regression. These results mostly fell below the 1:1 line suggesting these data exceeded the critical flux. The solid circles represented Arctic data (larger circles [30]; smaller circles [11]). The open circles represent Antarctic convergence sites where total sedimentary carbon oxidation rates had been calculated by models which included anaerobic metabolic rates [46]. Oxygen fluxes had been measured at these sites [16] and had been used in the regression. Both the Arctic and the newer Antarctic data coincide with the regression.

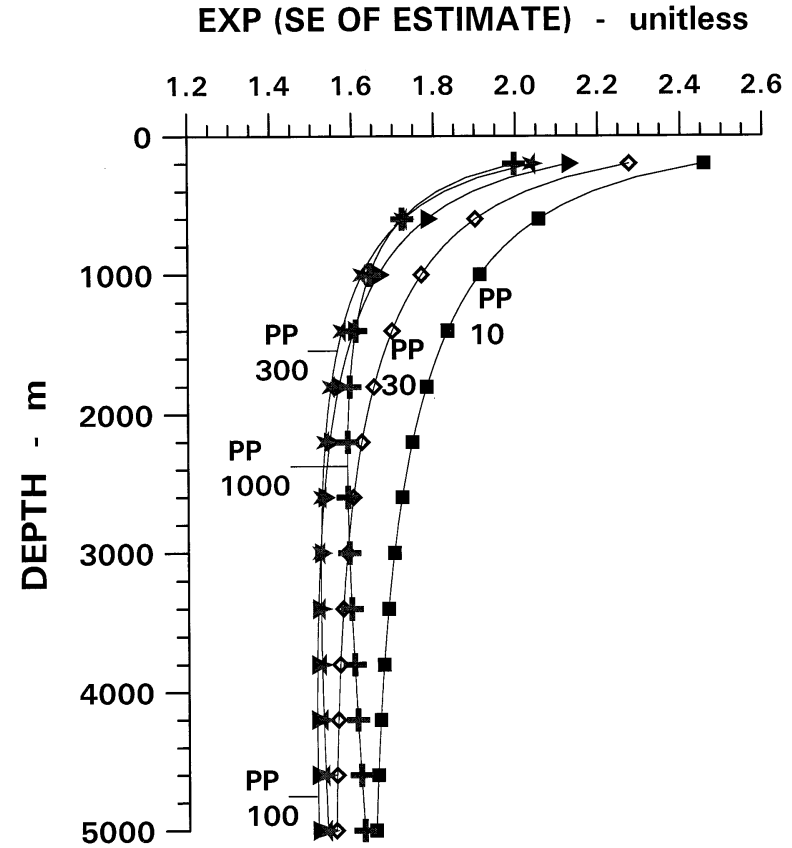

Figure 8. Depth distributions of the error factor $(\exp (\mathrm{SE}$ of estimate)) for different levels of primary productivity (PP, $\left.\mathrm{g} \cdot \mathrm{C} \cdot \mathrm{m}^{-2} \cdot \mathrm{y}^{-1}\right)$.

tivity of the incoming organic material. When this material was highly reactive (the depth dependent decay coefficient, $b$, was large), more of the oxygen utilization rate was nearer the sediment water interface so that more material could be oxidized aerobically. Consequently, in the oceans, both differences in the total influx and in the material's reactivity would affect the linearity between BOD and carbon influx. The presence of a diffusive boundary layer would lessen the ability of oxygen to enter the sediments but would be important only when the depth of the oxygenated sediments was relatively thin.

The model did not include any recycling of reduced compounds produced during anaerobic metabolism. Reduced products, such as diffusable ammonium or solid phase iron sulfides, could be transported back into the aerobic zone and could consume oxygen either via direct chemical reaction or via autotrophic consumption of oxygen [12, 15, 44, 48, 55]. This action would lessen the amount of oxygen available 
for organic matter respiration in the aerobic zone, and would increase the amount of organics available for anaerobic metabolism. The total oxygen consumption by sediments represents the sum of the aerobic respiration of organic matter and the oxidation of reduced inorganic compounds. However, anaerobic respiration is less efficient in generating energy per unit of carbon than is aerobic respiration, so that the net effect of this recycling would be to increase the proportion of organic matter consumed under anaerobic conditions relative to the model predictions. Consequently, model estimates (figure $3 a, b$ ) would be high of the real oxygen consumption due to aerobic organic matter oxidation. One study, [55], also examined the variation of oxygen consumption as a function of organic carbon input using a model that considered anaerobic metabolism and its linkage to oxygen consumption. That study showed that oxygen consumption closely approximated the carbon influx below $2-3 \mathrm{~g} \cdot \mathrm{C} \cdot \mathrm{m}^{-2} \cdot \mathrm{y}^{-1}$, but at larger influxes, the importance of oxic mineralization in consuming organic matter was reduced. At 120 $\mathrm{g} \cdot \mathrm{C} \cdot \mathrm{m}^{-2} \cdot \mathrm{y}^{-1}$, the oxic mineralization represented about $60 \%$ of the carbon influx. Their results fall between the curves for $\mathrm{b}=0.5$ and $\mathrm{b}=2.5$ in figure $3 b$. However, their model incorporated separate statistical fits of sedimentation rate, temperature dependence of the diffusivity, and irrigation rate onto water column depth. Also included were statistical fits of carbon oxidation rate at the sediment surface, influx of refractory carbon, bioturbation rate, and reduced sulfur reoxidation onto sedimentation rate. All of these externally imposed linkages would affect the details of their results. I chose the much simpler oxygen model to avoid ambiguity.

More complex models of oxygen in deep-sea sediments have also incorporated multiple types of organic matter, each with a different reaction

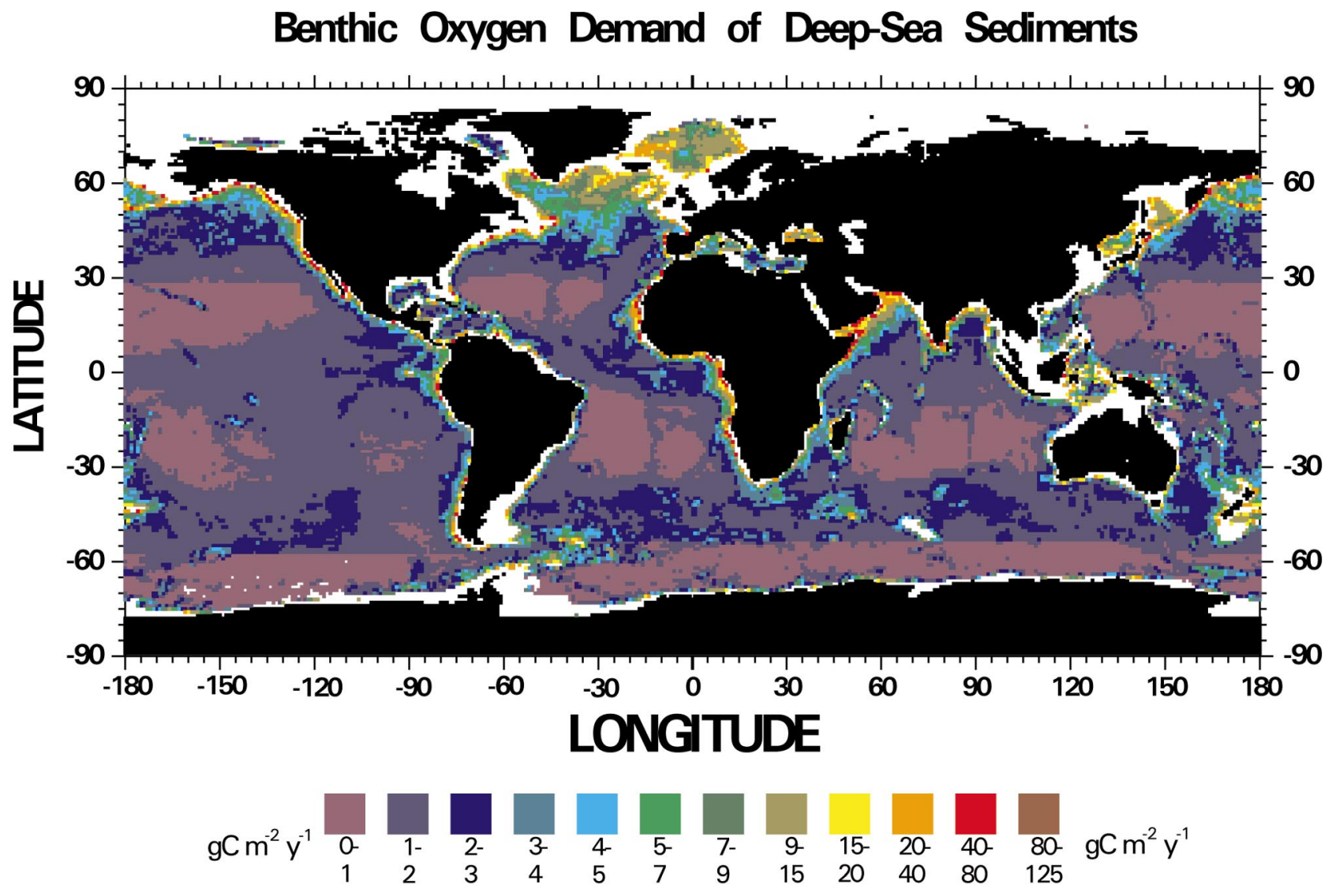

Figure 9. Global distribution of sediment BOD for sediments at depths of at least $1000 \mathrm{~m}$. 


\section{Carbon Fux to $1000 \mathrm{~m}$}

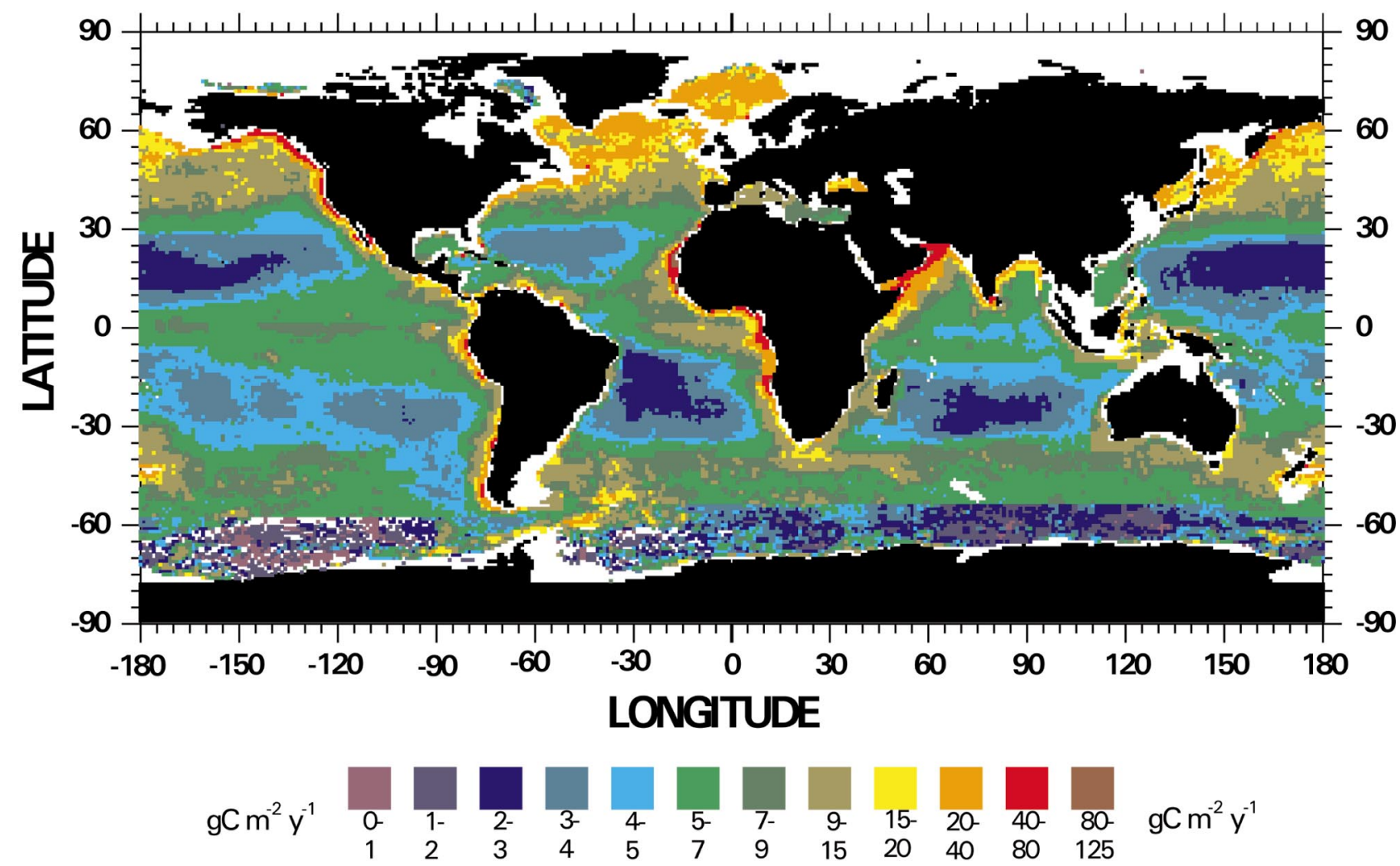

Figure 10. Global distribution of the downward flux of organic carbon at $1000 \mathrm{~m}$ for sites with water depths of at least $1000 \mathrm{~m}$.

coefficient, as well as a refractory organic matter type which is buried. The reasoning presented herein showed that a single type of reactive organic matter defines a critical organic carbon influx, above which oxygen diffusion is insufficient to maintain an aerobic sediment column. By analogy, two types of organic matter with different reactivities would result in two critical rates, one for each organic matter type. In this case, the critical rate for a particular sediment could vary if the relative proportions of the two organic matter types were to vary. Westrich and Berner [59] proposed that organic matter may contain materials of highly different reactivity, but found that coastal sites could be adequately approximated as having two types. Rabouille et al. [46] modeled sedimentary oxygen, nitrate, and organic matter profiles using rate constants for two reactable types of organic matter. Several studies utilized a continuum of organic matter fractions with different reaction rates [8, 58]. Rabouille and Gaillard [44, 45] showed that Monod kinetics for oxygen, nitrate, and manganese oxidation lead to reaction rate constants for organic matter which decrease dramatically with depth. Because experimental constraints on these different models are few, a simple model was employed in this study.

If the overall annual rate of productivity at a particular site is related in a direct way with the flux of sinking organic matter, then there should exist a relationship between surface productivity and BOD in sediments where BOD approximates the carbon influx. Using multilinear regression, a significant relationship relating water depth and productivity to the BOD was found (equation 12) and was similar in form to relationships between sediment trap collections and surface productivity $[4,6,34,35,38,41$, 56]. When compared to sediment trap results (figure 5 ), sediment BOD consistently exceeded the fluxes estimated from sediment trap relationships. Uncertainties in trap results have been discussed $[19,22$, 
Table III. Area $\left(10^{6} \mathrm{~km}^{2}\right)$ with both an average depth of at least $1000 \mathrm{~m}$ and measured primary productivity, percentage of ocean area lacking primary productivity assessments (Missing in percent of area), benthic oxygen demand (BOD, MT-C/y), and carbon flux at $1000 \mathrm{~m}$ depth $\left(\mathrm{C}_{\mathrm{flux}}, \mathrm{MT}-\mathrm{C} / \mathrm{y}\right)$ for latitudinal bands across the major oceans.

\begin{tabular}{|c|c|c|c|c|}
\hline Latitude & Area & Missing & BOD & $\mathrm{C}_{\text {flux }}$ \\
\hline \multicolumn{5}{|c|}{ ATLANTIC OCEAN } \\
\hline $70 \mathrm{~N}-60 \mathrm{~N}$ & 0.01 & 33.89 & 0.14 & 0.28 \\
\hline $60 N-50 N$ & 2.97 & 5.96 & 23.26 & 57.90 \\
\hline $50 \mathrm{~N}-40 \mathrm{~N}$ & 4.54 & 7.23 & 23.25 & 66.59 \\
\hline $40 \mathrm{~N}-30 \mathrm{~N}$ & 7.83 & 2.52 & 19.81 & 59.63 \\
\hline $30 N-20 N$ & 7.72 & 1.48 & 15.22 & 45.58 \\
\hline $20 \mathrm{~N}-10 \mathrm{~N}$ & 7.26 & 0.95 & 22.33 & 66.55 \\
\hline $10 \mathrm{~N}-0$ & 5.93 & 2.62 & 20.37 & 62.79 \\
\hline $0-10 \mathrm{~S}$ & 5.87 & 1.21 & 17.14 & 59.25 \\
\hline $10 \mathrm{~S}-20 \mathrm{~S}$ & 5.92 & 0.85 & 10.81 & 37.00 \\
\hline $20 \mathrm{~S}-30 \mathrm{~S}$ & 6.32 & 2.26 & 9.70 & 29.74 \\
\hline $30 \mathrm{~S}-40 \mathrm{~S}$ & 7.04 & 1.54 & 12.14 & 42.84 \\
\hline $40 \mathrm{~S}-50 \mathrm{~S}$ & 6.82 & 0.45 & 15.09 & 57.97 \\
\hline $50 \mathrm{~S}-60 \mathrm{~S}$ & 5.76 & 0.58 & 15.16 & 45.62 \\
\hline \multicolumn{5}{|c|}{ PACIFIC OCEAN } \\
\hline $70 \mathrm{~N}-60 \mathrm{~N}$ & 0.00 & 75.32 & 0.02 & 0.07 \\
\hline $60 \mathrm{~N}-50 \mathrm{~N}$ & 3.71 & 7.90 & 26.78 & 75.30 \\
\hline $50 \mathrm{~N}-40 \mathrm{~N}$ & 8.10 & 2.15 & 30.83 & 111.82 \\
\hline $40 \mathrm{~N}-30 \mathrm{~N}$ & 10.47 & 2.78 & 25.10 & 95.28 \\
\hline $30 \mathrm{~N}-20 \mathrm{~N}$ & 13.91 & 1.83 & 17.13 & 61.66 \\
\hline $20 \mathrm{~N}-10 \mathrm{~N}$ & 17.78 & 1.66 & 20.41 & 74.28 \\
\hline $10 \mathrm{~N}-0$ & 19.71 & 0.87 & 35.31 & 117.34 \\
\hline $0-10 \mathrm{~S}$ & 16.55 & 1.44 & 34.63 & 114.12 \\
\hline $10 \mathrm{~S}-20 \mathrm{~S}$ & 16.02 & 0.83 & 25.89 & 83.90 \\
\hline $20 \mathrm{~S}-30 \mathrm{~S}$ & 14.91 & 0.33 & 20.64 & 66.74 \\
\hline $30 \mathrm{~S}-40 \mathrm{~S}$ & 13.35 & 0.49 & 26.39 & 87.23 \\
\hline $40 \mathrm{~S}-50 \mathrm{~S}$ & 11.20 & 1.25 & 30.19 & 96.34 \\
\hline $50 \mathrm{~S}-60 \mathrm{~S}$ & 9.68 & 0.93 & 16.49 & 58.75 \\
\hline \multicolumn{5}{|c|}{ INDIAN OCEAN } \\
\hline $40 \mathrm{~N}-30 \mathrm{~N}$ & 0.34 & 3.21 & 0.89 & 2.70 \\
\hline $30 \mathrm{~N}-20 \mathrm{~N}$ & 3.07 & 11.77 & 13.88 & 34.90 \\
\hline $20 \mathrm{~N}-10 \mathrm{~N}$ & 7.63 & 5.50 & 32.90 & 84.83 \\
\hline $10 \mathrm{~N}-0$ & 9.03 & 2.60 & 24.25 & 70.93 \\
\hline $0-10 \mathrm{~S}$ & 9.14 & 3.40 & 22.40 & 64.79 \\
\hline $10 \mathrm{~S}-20 \mathrm{~S}$ & 9.16 & 1.20 & 14.12 & 46.02 \\
\hline $20 \mathrm{~S}-30 \mathrm{~S}$ & 8.39 & 1.26 & 11.22 & 36.07 \\
\hline $30 \mathrm{~S}-40 \mathrm{~S}$ & 10.33 & 2.07 & 20.60 & 71.64 \\
\hline $40 \mathrm{~S}-50 \mathrm{~S}$ & 10.81 & 0.26 & 23.79 & 81.00 \\
\hline $50 \mathrm{~S}-60 \mathrm{~S}$ & 8.84 & 0.00 & 10.75 & 38.11 \\
\hline \multicolumn{5}{|c|}{ ARCTIC OCEAN } \\
\hline $90 \mathrm{~N}-80 \mathrm{~N}$ & 0.00 & 99.47 & 0.00 & 0.00 \\
\hline $80 \mathrm{~N}-70 \mathrm{~N}$ & 1.17 & 48.10 & 10.65 & 22.69 \\
\hline $70 \mathrm{~N}-60 \mathrm{~N}$ & 1.71 & 16.77 & 20.27 & 38.26 \\
\hline $60 \mathrm{~N}-50 \mathrm{~N}$ & 0.00 & 9.18 & 0.00 & 0.00 \\
\hline \multicolumn{5}{|c|}{ ANTARCTIC } \\
\hline $60 \mathrm{~S}-70 \mathrm{~S}$ & 15.38 & 2.80 & 17.16 & 55.20 \\
\hline $70 \mathrm{~S}-80 \mathrm{~S}$ & 1.61 & 24.78 & 2.16 & 5.57 \\
\hline
\end{tabular}

39]. Also, sediment BOD represents a temporally longer average flux than short-term sediment trap deployments [31, 50, 53]. Non-linearity between BOD and carbon influx appears significant at influxes exceeding about $9 \mathrm{~g} \cdot \mathrm{C} \cdot \mathrm{m}^{-2} \cdot \mathrm{y}^{-1}$ (figure 7 ).

More importantly, the regression of deep-sea BOD versus productivity provides a unique means of evaluating sinking carbon fluxes in the ocean. Since deepsea sediments represent the extreme terminus of the vertical transport of material from the ocean surface, the relationship should represent a robust description of the amount of material surviving decomposition in its fall through the entire water column. The data used in the regression covers the range of water depths from 2 to $5.9 \mathrm{~km}$ and of productivities from $62-420 \mathrm{~g} \cdot \mathrm{C} \cdot \mathrm{m}^{-2} \cdot \mathrm{y}^{-1}$. The regression predicts the uncertainty in an estimated sediment BOD of less than a factor of 2 for depths between 1 and $5 \mathrm{~km}$, and the uncertainty increased by less than $50 \%$ for depths between 1000 and $200 \mathrm{~m}$ (figure 8). Also, the magnitude of the regression's uncertainty was about that of the natural sampling variability as found in replicate deep-sea BOD measurements [50]. This new regression predicted that the amount of productivity which is vertically exported increases approximately hyperbolically with higher productivities (figure 5). The proportion of the productivity reaching $1000 \mathrm{~m}$ increases from $4.2 \%$ at a productivity of $10 \mathrm{~g} \cdot \mathrm{C} \cdot \mathrm{m}^{-2} \cdot \mathrm{y}^{-1}$ to $5.8 \%$ at $100 \mathrm{~g} \cdot \mathrm{C} \cdot \mathrm{m}^{-2} \cdot \mathrm{y}^{-1}$ to $8.0 \%$ at $1000 \mathrm{~g} \cdot \mathrm{C} \cdot \mathrm{m}^{-2} \cdot \mathrm{y}^{-1}$ and to $9.7 \%$ at 4000 $\mathrm{g} \cdot \mathrm{C} \cdot \mathrm{m}^{-2} \cdot \mathrm{y}^{-1}$. More importantly, the measured deepsea sediment BOD appear to increase more rapidly with increasing productivity and to have greater rates than predicted by past sediment trap relationships (figure 5), suggesting that past interpretations of sediment trap results may have underestimated the flux of carbon into the deep-sea. It is possible that extrapolation of the regression to depths shallower $1000 \mathrm{~m}$ and to productivities greater than $420 \mathrm{~g} \cdot \mathrm{C} \cdot \mathrm{m}^{-2} \cdot \mathrm{y}^{-1}$ might lead to false predictions. The regression predicts that for a site with a productivity of 1000 $\mathrm{g} \cdot \mathrm{C} \cdot \mathrm{m}^{-2} \cdot \mathrm{y}^{-1}, 36 \%$ of the productivity would sink below $200 \mathrm{~m}$. However, this prediction is within the range of experimental determinations of export production and new production, excluding sediment traps, for many higher productivity regions $[18,25-$ 27], with the caveat that water column studies need to average over long time periods to obtain reasonable balances [14]. 
Table IV. Total primary production $\mathrm{P}_{\mathrm{p}}, \mathrm{BOD}$, and $\mathrm{C}_{\text {flux }}$ at $1000 \mathrm{~m}$ for all grid points of at least $1000 \mathrm{~m}$ depth, and $\mathrm{C}_{\text {flux }}$ at $2500 \mathrm{~m}$ for all grid points with depths of $2500 \mathrm{~m}$ or more for different oceans (units in MTC. $\mathrm{y}^{-1}$ ). Areas are in $10^{6} \mathrm{~km}^{2}$. Numbers in parentheses represent the percentage of each ocean to the global total.

\begin{tabular}{|c|c|c|c|c|c|c|}
\hline \multirow{2}{*}{$\begin{array}{c}\text { Reference } \\
\text { Process }\end{array}$} & \multicolumn{5}{|l|}{ OCEAN } & \multirow[t]{2}{*}{ TOTAL } \\
\hline & Atlantic & Pacific & Indian & Arctic & Antarctic & \\
\hline \multicolumn{7}{|l|}{ This Report } \\
\hline $\mathrm{P}_{\mathrm{p}}$ & $\begin{array}{l}10110 \\
(27)\end{array}$ & $\begin{array}{l}17319 \\
(45)\end{array}$ & $\begin{array}{l}8747 \\
(23)\end{array}$ & $\begin{array}{l}888 \\
(2)\end{array}$ & $\begin{array}{l}1075 \\
\text { (3) }\end{array}$ & 38139 \\
\hline BOD & $\begin{array}{l}204 \\
(28)\end{array}$ & $\begin{array}{l}310 \\
(42)\end{array}$ & $\begin{array}{l}175 \\
(24)\end{array}$ & $\begin{array}{l}31 \\
(4)\end{array}$ & $\begin{array}{l}19 \\
(3)\end{array}$ & 739 \\
\hline $\mathrm{C}_{\text {flux }} 1000 \mathrm{~m}$ & $\begin{array}{l}632 \\
(27)\end{array}$ & $\begin{array}{l}1043 \\
(42)\end{array}$ & $\begin{array}{l}531 \\
(23)\end{array}$ & $\begin{array}{l}61 \\
(3)\end{array}$ & $\begin{array}{l}61 \\
(3)\end{array}$ & 2328 \\
\hline $\mathrm{C}_{\text {flux }} 2500 \mathrm{~m}$ & $\begin{array}{l}226 \\
(32)\end{array}$ & $\begin{array}{l}394 \\
(56)\end{array}$ & $\begin{array}{l}51 \\
(7)\end{array}$ & $\begin{array}{l}11 \\
(2)\end{array}$ & $\begin{array}{l}22 \\
(3)\end{array}$ & 704 \\
\hline Area & $\begin{array}{l}74.0 \\
(23)\end{array}$ & $\begin{array}{l}155.4 \\
(48)\end{array}$ & $\begin{array}{l}76.7 \\
(24)\end{array}$ & $\begin{array}{l}2.9 \\
(1)\end{array}$ & $\begin{array}{l}17.0 \\
(5)\end{array}$ & 326.0 \\
\hline \multicolumn{7}{|l|}{ Jahnke [31] } \\
\hline BOD & 136 & 222 & 142 & - & - & 501 \\
\hline $\mathrm{C}_{\text {flux }} 1000 \mathrm{~m}$ & 298 & 509 & 301 & - & - & 1108 \\
\hline \multicolumn{7}{|c|}{ Broecker, Blanton, Smethie, Ostiund [9] } \\
\hline CfluX $2500 \mathrm{~m}$ & 276 & - & - & - & - & - \\
\hline Hinga [28] & - & - & - & - & - & - \\
\hline $\mathrm{C}_{\text {flux }} 2500 \mathrm{~m}$ & 157 & 534 & - & - & - & - \\
\hline
\end{tabular}

This relationship between productivity and deep-sea BOD was applied to global distributions of productivity and bathymetry to produce global maps of sediment BOD and organic carbon flux to $1000 \mathrm{~m}$ depth (figures 9,10). Although it could be argued that global maps of productivity are inaccurate, several satellite-based global distributions of productivity were found to agree within $10 \%[1,2]$. The distribution used in this report [37] was about $10 \%$ greater than more recent ones, but when the water-leaving radiance was adjusted in turbid coastal waters, their global productivity was identical to the other distributions. In the global distributions and their summations (figures 9,11), localities with water depths less than $1000 \mathrm{~m}$ were not considered, so that the uncertainties in the coastal regions would not affect these new results.

This new relationship differs with that described by Jahnke [32], where rates of carbon burial were correlated with sediment oxygen fluxes (BOD). Since burial in deep-sea sediments frequently represents only a few percent of the total influx, that correlation had a large variability associated with it. Nevertheless, that relationship was extrapolated globally based on large-scale global maps of both organic carbon in surface sediments and sediment accumulation rates [32]. Those global sediment oxygen fluxes were then compared with the sinking organic matter fluxes found with sediment traps and crudely estimated maps of productivity [4]. From this comparison, Jahnke [32] suggested that $3.0 \%$ of the global primary productivity reaches the $1000 \mathrm{~m}$ depth, and that sediments consume $45 \%$ of the deep flux. In the present report, the sum of the annual global sediment BOD was $48 \%$ greater than that of Jahnke [32]. This new result is greater both because the sediments appear to capture more organic matter than estimated from sediment traps and because the topographic and productivity maps allowed the calculation of fluxes at a higher spatial resolution as well as in the marginal seas of each of the major oceans, places that were excluded in that study. The new regression predicts that about $6 \%$ of the productivity in the deep-water areas reaches $1000 \mathrm{~m}$, a flux $210 \%$ as great as that calculated by Jahnke [32]. As a result, the new regression indicates that sediments consume only $32 \%$ of the material sinking though $1000 \mathrm{~m}$.

These new results can be compared with the oxygen consumption rates calculated from relationships be- 
tween Apparent Oxygen Utilization (AOU) and ${ }^{14} \mathrm{TCO}_{2}$ found in deep waters of the major oceans $[9$, 28]. These deep water data were from depths generally greater than $2500 \mathrm{~m}$, so the $1000 \mathrm{~m}$ flux estimate given above needs to be corrected. By restricting the portion of the ocean to those areas with depths greater than or equal to $2500 \mathrm{~m}$ and then adjusting the flux for the organic matter decay occurring between 1000 and $2500 \mathrm{~m}$, the resulting influx into waters below $2500 \mathrm{~m}$ was $226 \mathrm{MT} \cdot \mathrm{y}^{-1}$ in the Atlantic (table IV). This value is intermediate between the estimates of $276 \mathrm{MT} \cdot \mathrm{y}^{-1}$ [9] and of 157 $\mathrm{MT} \cdot \mathrm{y}^{-1}$ [28] (table IV). Thus, the results from this analysis concur with the deep water column AOU/ ${ }^{14} \mathrm{C}$ results, suggesting that the regression results extrapolated globally are realistic.

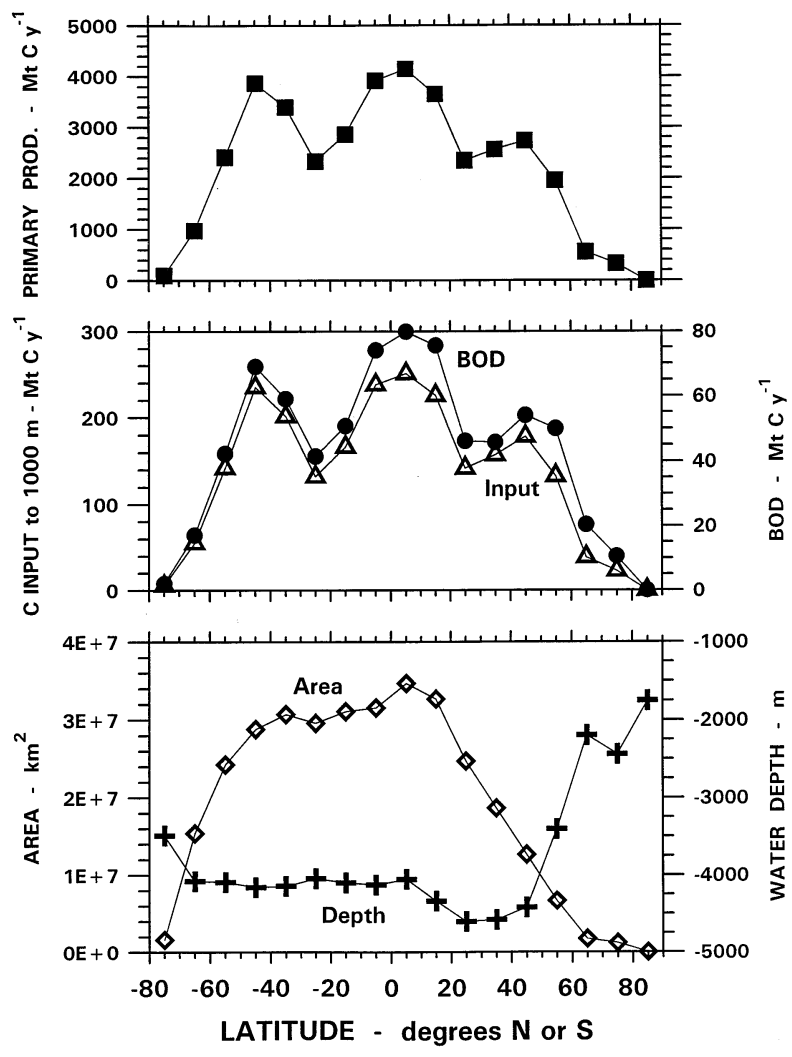

Figure 11. Latitudinal distribution of primary productivity, sediment BOD, downward carbon flux at $1000 \mathrm{~m}$ depth, area, and average water depth. Data represented sums over ten-degree latitudinal bands for locations with water depths at least $1000 \mathrm{~m}$ and where productivity estimates were available.
It has been suggested that polar ice-covered pelagic ecosystems may loose a greater fraction of their productivity into deep waters [43]. Two studies from the seasonally or permanently ice-covered Arctic, one in the Fram Strait region [30] and one under the Arctic ice cap [11] measured deep-sea BOD. Using measured productivities in the surface waters (about $15 \mathrm{~g} \cdot \mathrm{C} \cdot \mathrm{m}^{-2} \cdot \mathrm{y}^{-1}$ under the ice cap [21,60], and about $80 \mathrm{~g} \cdot \mathrm{C} \cdot \mathrm{m}^{-2} \cdot \mathrm{y}^{-1}$ in the Fram Strait region [54]), the measured BODs and the carbon influx predicted by equation 12 agree well with the lower latitude relationship (figure 7). Consequently, these few Arctic data do not support the idea of anomalously greater vertical export in polar ice-covered regions.

\section{Acknowledgements}

This work was supported by United States National Science Foundation grants OPP-9400058, OCE-9617960, OPP-9530774 and OPP-9905947, and is contribution number 99003 from Bigelow Laboratory for Ocean Sciences.

\section{REFERENCES}

[1] Behrenfeld M.J., Falkowski P.G., Photosynthetic rates derived from satellite-based chlorophyll concentration, Limnol. Oceanogr. 42 (1997a) 1-20.

[2] Behrenfeld M.J., Falkowski P.G., A consumer's guide to phytoplankton primary productivity models, Limnol. Oceanogr. 42 (1997b) 1479-1491.

[3] Berelson W.H., Hammond D.E., O’Neill D., Xu X.-M., Chin C., Zukin J., Benthic fluxes and pore water studies from sediments of the central equatorial north Pacific: nutrient results, Geochim. Cosmochim. Acta 54 (1990) 3001-3012.

[4] Berger W.H., Fischer K., Lai C., Wu G., Ocean carbon flux: global maps of primary production and export production, in: Agegian C.R. (Ed.), Biogeochemical Cycling and Fluxes Between the Deep Euphotic Zone and Other Oceanic Realms, U.S. Undersea Research Program Research Report 88-1, 1988, pp. 131-176.

[5] Berner R.A., Early Diagenesis, A Theoretical Approach, Princeton University Press, Princeton N.J, 1980, p. 241.

[6] Betzer P.R., Showers W.J., Laws E.A., Winn C.D., Ditullio G.R., Kroopnick P.M., Primary productivity and particle fluxes on a transect of the equator at $153^{\circ} \mathrm{W}$ in the Pacific Ocean, Deep-Sea Res. 31 (1984) 1-11.

[7] Billett D.S.H., Lampitt R.S., Rice A.L., Mantoura R.F.C., Seasonal sedimentation of phytoplankton to the deep-sea benthos, Nature 302 (1983) 520-522. 
[8] Boudreau B.P., Ruddick B.R., On a reactive continuum representation of organic matter diagenesis, Amer. J. Sci. 291 (1991) 507-538.

[9] Broecker W.S., Blanton S., Smethie W.M Jr., Ostlund G., Radiocarbon decay and oxygen utilization in the deep Atlantic Ocean, Global Biogeochem. Cycles 5 (1991) 87-117.

[10] Cai W-J, Reimers C.E., Benthic oxygen flux, bottom water oxygen concentration and core top organic carbon content in the deep northeast Pacific Ocean, Deep-Sea Res. 42 (1995) $1681-1699$.

[11] Christensen J.P., Oxygen and nutrients in deep-sea sediment pore waters of the Arctic Ocean, Mar. Chem., submitted.

[12] Christensen J.P., Rowe G.T., Nitrification and oxygen consumption in northwest Atlantic deep-sea sediments, J. Mar. Res. 42 (1984) 1099-1116.

[13] Cole J.J., Honjo S., Erez J., Benthic decomposition of organic matter at a deep-water site in the Panama Basin, Nature 327 (1982) 703-704.

[14] Dauchez S., Legendre L., Fortier L., Levasseur M., New production and production of large phytoplankton $(>5 \mu \mathrm{m})$ on the Scotian Shelf (NW Atlantic), Mar. Ecol. Prog. Series 135 (1996) 215-222.

[15] Devol A.H., Christensen J.P., Benthic fluxes and nitrogen cycling in sediments of the continental margin of the eastern North Pacific, J. Mar. Res. 51 (1993) 345-372.

[16] De Wit R., Relexans J-C, Bouvier T., Moriarty D.J.W., Microbial respiration and diffusive oxygen uptake of deep-sea sediments in the Southern Ocean (ANTARES-I cruise), DeepSea Res. 44 (1997) 1053-1068.

[17] Emerson S., Organic carbon preservation in marine sediments, in: Sundquist E.T., Broecker W.S. (Eds.), The Carbon Cycle and Atmospheric CO2: Natural Variations Archean to Present, American Geophysical Union, Washington DC, 1985 , pp. $78-88$.

[18] Eppley R.W., Peterson B.J., Particulate organic matter flux and planktonic new production in the deep ocean, Nature 282 (1979) 677-680.

[19] Gardner W.D., The effect of tilt on sediment trap efficiency, Deep-Sea Res. 32 (1985) 349-361.

[20] Glud R.N., Gundersen J.K., Jorgensen B.B., Revsbech N.P., Schultz H.D., Diffusive and total oxygen uptake of deep-sea sediments in the eastern South Atlantic Ocean: in situ and laboratory measurements, Deep-Sea Res. 41 (1994) 17671788.

[21] Gosselin M., Levasseur M., Wheeler P.A., Horner R.A., Booth B.C., New measurements of phytoplankton and ice algal production in the Arctic Ocean, Deep-Sea Res. 44 (1997) $1623-1644$.

[22] Gust G., Michaels A.F., Johnson R., Deuser W.G., Bowles W., Mooring line motions and sediment trap hydrodynamics: in situ intercomparison of three common deployment designs, Deep-Sea Res. 41 (1994) 831-857.

[23] Hales B., Emerson S., Calcite dissolution in sediments of the Ontong-Java Plateau: in situ measurements of pore water $\mathrm{O}_{2}$ and pH, Global Biogeochem. Cycles 10 (1996) 527-541.
[24] Hales B., Emerson S., Archer D., Respiration and dissolution in the sediments of the western North Atlantic: estimates from models of in situ microelectrode measurements of porewater oxygen and pH, Deep-Sea Res. 41 (1994) 695-719.

[25] Harrison W.G., Platt T., Lewis M.R., f-Ratio and its relationship to ambient nitrate concentration in coastal waters, J. Plankton Res. 9 (1987) 235-248.

[26] Harrison W.G., Head E.J.H., Horne E.P.W., Irwin B., Li W.K.W., Longhurst A.R., Paranjape M.A., Platt T., The western North Atlantic Bloom Experiment, Deep-Sea Res. 40 (1993) 279-305.

[27] Head E.J.H., Harrison W.G., Irwin B.I., Horne E.P.W., Li W.K.W., Plankton dynamics and carbon flux in an area of upwelling off the coast of Morocco, Deep-Sea Res. 43 (1996) $1713-1738$.

[28] Hinga K.R., Evidence for a higher average primary productivity in the Pacific than in the Atlantic Ocean, Deep-Sea Res. 32 (1985) 117-126.

[29] Hornbeck R.W., Numerical Methods, Quantam Publishers, NY, 1975, p. 310.

[30] Hulth S., Blackburn T.H., Hall P.O.J., Arctic sediments (Svalbard): consumption and microdistribution of oxygen, Mar. Chem. 46 (1994) 293-316.

[31] Jahnke R.A., The global ocean flux of particulate organic carbon: Areal distribution and magnitude, Global Biogeochem. Cycles 10 (1996) 71-88.

[32] Jahnke R.A., Craven D.B., Gaillard J-F., The influence of organic matter diagenesis on $\mathrm{CaCO}_{3}$ dissolution at the deepsea floor, Geochim. Cosmochim. Acta 58 (1994) 2799-2809.

[33] Jahnke R.A., Emerson S.R., Reimers C.E., Schuffert J., Ruttenberg K., Archer D., Benthic recycling of biogenic debris in the eastern tropical Atlantic Ocean, Geochim. Cosmochim. Acta 53 (1989) 2947-2960.

[34] Jickells T.D., Newton P.P., King P., Lampitt R.S., Boutle C., A comparison of sediment trap records of particle fluxes from 19 to $48^{\circ} \mathrm{N}$ in the northeast Atlantic and their relation to surface water productivity, Deep-Sea Res. 43 (1996) 971-986.

[35] Lampitt R.S., Anita A.N., Particle flux in deep seas: regional characteristics and temporal variability, Deep-Sea Res. 44 (1997) 1377-1403.

[36] Lampitt R.S., Raine R.C.T., Billett D.S.M., Rice A.L., Material supply to the European continental slope: a budget based on benthic oxygen demand and organic supply, Deep-Sea Res. 42 (1988) 1865-1880.

[37] Longhurst A., Sathyendranath S., Platt T., Caverhill C., An estimate of global primary production in the ocean from satellite radiometer data, J. Plankton Res. 17 (1995) 12451271.

[38] Martin J.H., Knauer G.A., Karl D.M., Broenkow W.W., VERTEX: carbon cycling in the northeast Pacific, Deep-Sea Res. 34 (1987) 267-285.

[39] Michaels A.F., Silver M.W., Gwing M.M., Knauer G.A., Cryptic zooplankton "swimmers" in upper ocean sediment traps, Deep-Sea Res. 37 (1990) 1285-1296. 
[40] Muller P.J., Suess E., Productivity sedimentation rate and sedimentary organic matter in the oceans, I, Organic carbon preservation, Deep-Sea. Res. 26 (1979) 1347-1367.

[41] Pace M.L., Knauer G.A., Karl D.M., Martin J.H., Primary production, new production and vertical flux in the eastern Pacific Ocean, Nature 325 (1987) 803-804.

[42] Patching J.W., Raine R.C.T., Barnett P.R.O., Watson J., Abyssal benthic oxygen consumption in the Northeastern Atlantic: measurements using the suspended core technique, Oceanol. Acta 9 (1994) 1-7.

[43] Pomeroy L.R., Wiebe W.J., Deibel D., Thompson R.J., Rowe G.T., Pakulski J.D., Bacterial responses to temperature and substrate concentration during the Newfoundland spring bloom, Mar. Ecol. Prog. Ser. 75 (1991) 143-159.

[44] Rabouille C., Gaillard J.-F., Towards the EDGE: Early diagenetic global explanation. A model depicting the early diagenesis of organic matter, $\mathrm{O}_{2}, \mathrm{NO}_{3}, \mathrm{Mn}$ and $\mathrm{PO}_{4}$, Geochim. Cosmochim. Acta 55 (1991a) 2511-2525.

[45] Rabouille C., Gaillard J.-F., A coupled model representing the deep-sea organic carbon mineralization and oxygen consumption in surficial sediments, J. Geophys. Res. 96 (1991b) $2762-$ 2776.

[46] Rabouille C., Gaillard J.-F., Relexans J.-C., Treguer P., Vicendeau M.-A., Recycling of organic matter in Antarctic sediments: A transect through the polar front in the Southern Ocean (Indian Sector), Limnol. Oceanogr. 43 (1998) 420432.

[47] Relexans J.-C., Deming J., Dinet A., Gaillard J.-F., Sibuet M., Sedimentary organic matter and micro-meiobenthos with relation to trophic conditions in the tropical northeast Atlantic, Deep-Sea Res. 43 (1996) 1343-1368.

[48] Reimers C.E., Jahnke R.A., McCorkle D.C., Carbon fluxes and burial rates over the continental slope and rise off central California with implications for the global carbon cycle, Global Biogeochem. Cycles 6 (1992) 199-224.

[49] Rowe G.T., Boland G.S., Phoel W.C., Anderson R.F., Biscaye P.E., Deep-Sea floor respiration as an indication of lateral input of biogenic detritus from continental margins, Deep-Sea Res. 41 (1994) 657-668.
[50] Sayles F.L., Martin W.R., Deuser W.G., Response of benthic oxygen demand to particulate organic carbon supply in the deep sea near Bermuda, Nature 371 (1994) 686-689.

[51] Smith K.L. Jr., Food energy supply and demand: A discrepancy between particulate organic carbon flux and sediment community oxygen consumption in the deep ocean, Limnol. Oceanogr. 32 (1987) 201-220.

[52] Smith K.L. Jr., Carlucci A.F., Jahnke R.A., Craven D.B., Organic carbon mineralization in the Santa Catalina Basin: benthic boundary layer metabolism, Deep-Sea Res. 34 (1987) $185-211$.

[53] Smith K.L. Jr., Baldwin R.J., Williams P.M., Reconciling particulate organic carbon flux and sediment community oxygen consumption in the deep North Pacific, Nature 359 (1992) 313-316.

[54] Smith W.O. Jr., Codispoti L.A., Nelson D.M., Manley T., Buskey E.J., Niebauer H.J., Cota G.F., Importance of Phaeocyctis blooms in the high-latitude ocean carbon cycle, Nature 352 (1991) 514-5156.

[55] Soetaert K., Herman P.M.J., Middelburg J.J., A model of early diagenetic processes from the shelf to abyssal depths, Geochim. Cosmochim. Acta 60 (1996) 1019-1040.

[56] Suess E., Particulate organic carbon flux in the oceans surface productivity and oxygen utilization, Nature 288 (1980) $260-263$.

[57] Ullman W.J., Aller R.C., Diffusion coefficients in nearshore marine sediments, Limnol. Oceanogr. 27 (1982) 552-556.

[58] Van Cappellen P., Gaillard J.-T., Rabouille C., Biogeochemical transformations in sediments: kinetic models of early diagenesis, in: Wollast R., MacKenzie F.T., Chow I. (Eds.), Interactions of $\mathrm{C}, \mathrm{N}, \mathrm{P}$ and $\mathrm{S}$ Biogeochemical Cycles and Global Change, Springer-Verlag, 1993, pp. 401-446.

[59] Westrich J.T., Berner R.A., The role of sedimentary organic matter in bacterial sulfate reduction: The $G$ model tested, Limnol. Oceanogr. 29 (1984) 236-249.

[60] Wheeler P.A., Gosselin M., Sherr E., Thilbault D., Kirchmand D.L., Benner R., Whitledge T.E., Active cycling of organic carbon in the central Arctic Ocean, Nature 380 (1996) 697-699. 